\title{
Distribution and Characterization of Different Molecular Products of Pro-somatostatin in the Hypothalamus and Posterior Pituitary Lobe of the Mongolian Gerbil (Meriones unguiculatus)
}

\author{
Philip J. Larsen, ${ }^{1}$ Maurizio Bersani, ${ }^{2}$ Jens J. Holst, ${ }^{2}$ Morten Møller, ${ }^{1}$ and Jens D. Mikkelsen ${ }^{1}$ \\ IInstitute of Medical Anatomy B and Institute of Medical Physiology C, University of Copenhagen, \\ DK-2200 Copenhagen N, Denmark
}

Antisera raised against various synthetic peptide fragments of the pro-somatostatin molecule were used to visualize immunohistochemically the distributions of different pro-somatostatin fragments in the hypothalamus and posterior pituitary of the Mongolian gerbil. To define the nature of the immunoreactive somatostatin-related molecular forms, gel chromatography combined with radioimmunoassays of hypothalamic and posterior pituitary extracts was performed. Within the hypothalamus, only trace amounts of somatostatin-28 and somatostatin-28(1-12) were present, whereas pro-somatostatin(1-76), pro-somatostatin(1-64), and somatostatin-14 peptides were present in equimolar amounts. In contrast, the posterior pituitary lobe contained equal amounts of somatostatin-14, somatostatin-28, and somatostatin-28(1-12) but no pro-somatostatin(1-76), indicating that pro-somatostatin is further processed during the axonal flow to posterior pituitary nerve terminals. The gel chromatographic data were further substantiated by immunohistochemical data. Thus, perikarya containing all of these five immunoreactivities were strictly confined to the periventricular area and parvocellular subset of the paraventricular nucleus. However, the number of somatostatin-28- and somatostatin-28(1-12)-immunoreactive perikarya was approximately $20 \%$ of the number of somatostatin-14- and pro-somatostatin(1-64)-immunoreactive cells. In other hypothalamic areas only somatostatin-14 and pro-somatostatin(1-64) immunoreactivities were detectable in cell bodies. These cell bodies were encountered in the organum vasculosum laminae terminalis; the suprachiasmatic, ventromedial, arcuate, perifornical, and posterior hypothalamic nuclei; and the median preoptic and retrochiasmatic areas. In situ hybridization histochemistry revealed that the cellular distribution of pro-somatostatin mRNA corresponds to that of somatostatin-14 and pro-somatostatin immunoreactivity, suggesting that the immunoreactive material observed within the cell bodies is synthetized there and that the differences in density of immunoreactivities may be explained by

\footnotetext{
Received May 30, 1991; revised Sept. 9, 1991; accepted Oct. 18, 1991.

We thank Ms. L. R. Olsen for skillful technical assistance. This study was supported by Nordisk Insulinfond, Dr.med.vet. Axel Thomsen and hustru Martha Thomsen f. Haugen-Johansens Legat, Dir. Jacob Madsen og hustru Olga Madsens Fond, Fonden til Lagevidenskabens fremme, P. Carl Petersens Fond, The Danish Medical Research Council (J. 12-9148 and 12-9742), and The Danish "Biotechnology Programme" (Centre for Neuropeptide Research).

Correspondence should be addressed to Philip Just Larsen, M.D., Institute of Medical Anatomy, Department B, The Panum Institute, Blegdamsvej 3, DK-2200 Copenhagen N, Denmark.

Copyright (C) 1992 Society for Neuroscience $0270-6474 / 92 / 120946-16 \$ 05.00 / 0$
}

intracellular processing of pro-somatostatin. Somatostatinergic nerve fibers and terminals in hypothalamic areas and the posterior pituitary lobe were immunoreactive to all of the employed antisera.

From the present results, obvious differences between intrahypothalamic and hypothalamo-pituitary somatostatinergic neurons emerge. Within hypothalamic neurons not projecting to the median eminence and the posterior pituitary lobe, pro-somatostatin is posttranslationally processed in the cell body predominantly into pro-somatostatin(1-64) and somatostatin-14. Otherwise, within periventricular neurons projecting to the median eminence and the posterior pituitary lobe, pro-somatostatin is posttranslationally processed during the axonal flow into pro-somatostatin(1-64), somatostatin-14, somatostatin-28, and somatostatin-28(1-12).

Originally, the tetradecapeptide somatostatin-14 (SS-14) was isolated from the porcine hypothalamus and shown to inhibit the release of growth hormone from the anterior pituitary lobe (Brazeau et al., 1973). Later, cDNAs coding for human and rat prepro-SS have been cloned and the peptide sequences deduced (Shen et al., 1982; Goodman et al., 1983). Gel filtration and sequence analysis of gastrointestinal and hypothalamic extracts from several species have revealed the following putative posttranslational processing products of pro-SS: an N-terminal prosomatostatin(1-64) [pro-SS(1-64)] molecule and a peptide consisting of the remaining $28 \mathrm{C}$-terminal amino acids of pro-SS, somatostatin-28 (SS-28) (Pradayrol et al., 1980; Schally ct al., 1980; Goodman et al., 1983; Holst et al., 1988; Bersani et al., 1989). SS-28 contains a typical prohormone cleavage site and may be further processed into the C-terminal SS-14 and the N-terminal SS-28(1-12), both widely distributed throughout the brain (Benoit et al., 1982, 1984). The role of SS-14 and SS-28 as neurotransmitters/neurohormones is well established (Meyers et al., 1980; Lumpkin et al., 1981; Reichlin, 1983; Enjalbert et al., 1986; Brown et al., 1988; Meyer et al., 1989). Less is known about the physiological functions of SS-28(1-12), and some authors regard it as a fragment of no physiological importance (Vécsei and Widerlöw, 1990). In brain areas, the relative content of SS-14, SS-28, and SS-28(1-12) varies (Benoit et al., 1982, 1984; Gomez et al., 1983). Although prohormones have been considered to be less biologically active than their final products, SS-28 is, with regard to some peripheral actions, more potent than SS-14 (e.g., the inhibition of growth hormonc release from the anterior pituitary lobe) (Tannenbaum et al., 1982). This is supported by the observation that SS-28 exhibits higher affinity to SS-14 receptors in the pituitary than SS-14, 
Table 1. Schematic presentation of the peptide fragments of the proSS molecule recognized by the antisera employed in this study

\begin{tabular}{lllll} 
& \multicolumn{3}{l}{ Antisera } & \\
\cline { 2 - 5 } Fragment & 1654 & 1758 & 2098 & 4576 \\
\hline pro-SS(1-64) & - & - & + & - \\
pro-SS(1-76) & - & - & + & + \\
SS-28(1-12) & - & - & - & + \\
SS-14 & - & + & - & - \\
SS-28 & + & + & - & -
\end{tabular}

Positive response is depicted with a plus sign, while negative is depicted by a minus sign.

whereas in the brain, SS-28 exhibits a lower affinity than SS-14 for the receptor (Srikant and Patel, 1981; Leroux et al., 1985; Reubi and Maurer, 1985). In the gastrointestinal tract, the proSS(1-64) peptide has been shown to be a major product of processing of pro-SS (Holst et al., 1988; Bersani et al., 1989). Recently, a $7 \mathrm{kDa}$ peptide fragment of the $\mathrm{N}$-terminal part of the pro-SS molecule has been shown to be present in high amounts in the rat nervous system (Rabbani and Patel, 1990), and this peptide is suggested to be identical to pro-SS(1-63). However, the functional significance of pro-SS(1-64) or pro-SS(1-63) is at present unknown.

In the hypothalamus, somatostatinergic neurons are mainly localized in the periventricular cell group extending from the preoptic area to the median eminence (Hökfelt et al., 1975; Krisch, 1978; Dierickx and Vandesande, 1979). Lesion studies have shown that these cells are the main origin of the somatostatinergic nerve terminals in the perivascular spaces surrounding the portal vessels of the median eminence (Ibata et al., 1983; Beal et al., 1985). This projection is likely to influence the release of growth hormone from pituitary somatotrophs via a release of SS-14, SS-28, and SS-28(1-12) to the portal blood (Millar et al., 1983; Sheward et al., 1984; Pierotti et al., 1985). Apart from the periventricular area/median eminence-projecting neurons, somatostatinergic cell bodies and nerve fibers are present in several other hypothalamic areas as well as the posterior pituitary lobe (Hökfelt et al., 1975; Patel and Reichlin, 1978; Dierickx and Vandesande, 1979; Hoffman and Hayes, 1979). Thus, in addition to the somatostatinergic neuroendocrine system in the hypothalamus, a population of somatostatinergic neurons, which may also involve hypothalamic neurons, give rise to intracerebral projections. It is tempting to speculate that the pro-SS molecule undergoes differential posttranslational processing dependent on whether the final product serves as a hypophysiotropic factor or an intracerebral transmitter substance.

The present study was undertaken to shed light on the anatomical distribution of pro-SS-derived peptide fragments in the hypothalamus and to identify the posttranslational processing products of pro-SS in different hypothalamic areas. By employing a wide variety of antisera recognizing different regions of the pro-SS molecule [pro-SS(20-36), SS-14, SS-28, and SS-28(112)], we have combined immunohistochemical visualization of

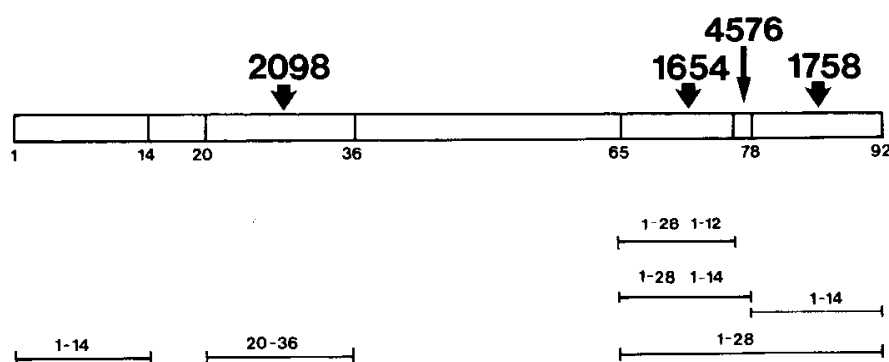

Figure 1. Diagrammatic representation of the pro-SS molecule. Binding regions of the various antisera employed in the present study are indicated. Antiserum 4576 recognizes the C-terminus of pro-SS(1-76) and SS-28(1-12) only when SS-14 is split off from pro-SS. Antiserum 1654 recognizes the full sequence of SS-28, but neither SS-14 nor SS28(1-12).

neuronal elements with the gel chromatographic characterization of the immunoreactivities in hypothalamic extracts of the gerbil. This approach makes it possible to reveal the actual peptides present within cell bodies and their fate during axonal transport to nerve terminals (Lewis et al., 1986). To investigate that transcription of the prepro-SS gene is in fact further translated through peptide synthesis, we used in situ hybridization histochemistry to localize pro-SS mRNA in the hypothalamus. Furthermore, by comparing the data obtained by in situ hybridization histochemistry with the immunohistochemical data, it was possible to compare the regional synthetic activity with the content of the corresponding peptide.

\section{Materials and Methods}

Antisera. The antisera used in the present study were raised in rabbits as described in Holst and Åsted (1974). Antisera were raised against the following synthetic pro-SS fragments: $20-36$ fragment of pro-SS (code 2098), carboxy-terminal part of SS-28(1-12) (code 4576), SS-28 (code 1654), and SS-14 (code 1758). The epitopes recognized by the various antisera are depicted in Figure 1 and Table 1 . The antisera have previously been characterized in detail: The 2098 antiserum recognizes the 20-36 amino acid sequence of the pro-SS molecule and thus proSS-like immunoreactivity (pro-SS-LI) could represent the 20-36 fragment alone or extended versions thereof (Bersani et al., 1989). The 4576 antiserum recognizes the carboxy-terminal part of the SS-28(1-12) molecule but not C-terminally extended forms, and thus SS-28(1-12)-LI could represent SS-28(1-12) as well as amino-terminally extended forms of this part (Skak-Nielsen et al., 1987). Since the 1654 antisera recognizes a part of the amino acid sequence linking the SS-28(1-12) and SS-14, it does not react with either SS-28(1-12) or SS-14 separately after these peptide fragments have been formed from the cleavage of SS-28 (Holst et al., 1988). Finally, the 1758 antiserum recognizes the carboxy-terminal part of the SS-14 molecule, and thus SS-14-LI could represent SS-14 as well as SS-28 (Baldissera et al., 1983). For immunohistochemistry, the antisera were diluted in potassium phosphate-buffered saline (KPBS; pH 7.4) containing 0.3\% Triton X-100 (TX-100) and $1.0 \%$ BSA (KPBS-BT). The dilutions were as follows: codes 1758 and 2098, 1:1000; codes 4576 and $1654,1: 400$.

Immunohistochemistry. Fifteen adult male Mongolian gerbils weighing 50-70 gm were anesthetized with tribromomethanol $(250 \mathrm{mg} / \mathrm{kg}$ body weight, i.p.) and perfused via the vascular system with $0.05 \mathrm{~m}$ potassium phosphate-buffered saline (KPBS; $\mathrm{pH}, 7.4)$ containing heparin (15,000 IU/liter) for $3 \mathrm{~min}$, followed by perfusion with $4 \%$ paraformaldehyde in $0.1 \mathrm{M}$ phosphate buffer $(\mathrm{pH}, 7.4)$ for $15 \mathrm{~min}$. The brains

Figure 2. Camera lucida drawings of coronal sections through the gerbil preoptic area and hypothalamus illustrating the distribution of immunoreactive nerve fibers $(l e f t)$ and cell bodies (right). The left column indicates the staining pattern seen after immunohistochemical visualization with antisera 1758 and 2098 , whereas the right column indicates the distribution of immunoreactive elements after the use of antisera 1654 and 4576. Black dots indicate stained cell bodies, and short thin lines indicate labeled nerve fibers and terminals. For abbreviations, see Appendix. 
$1758 \& 2098$
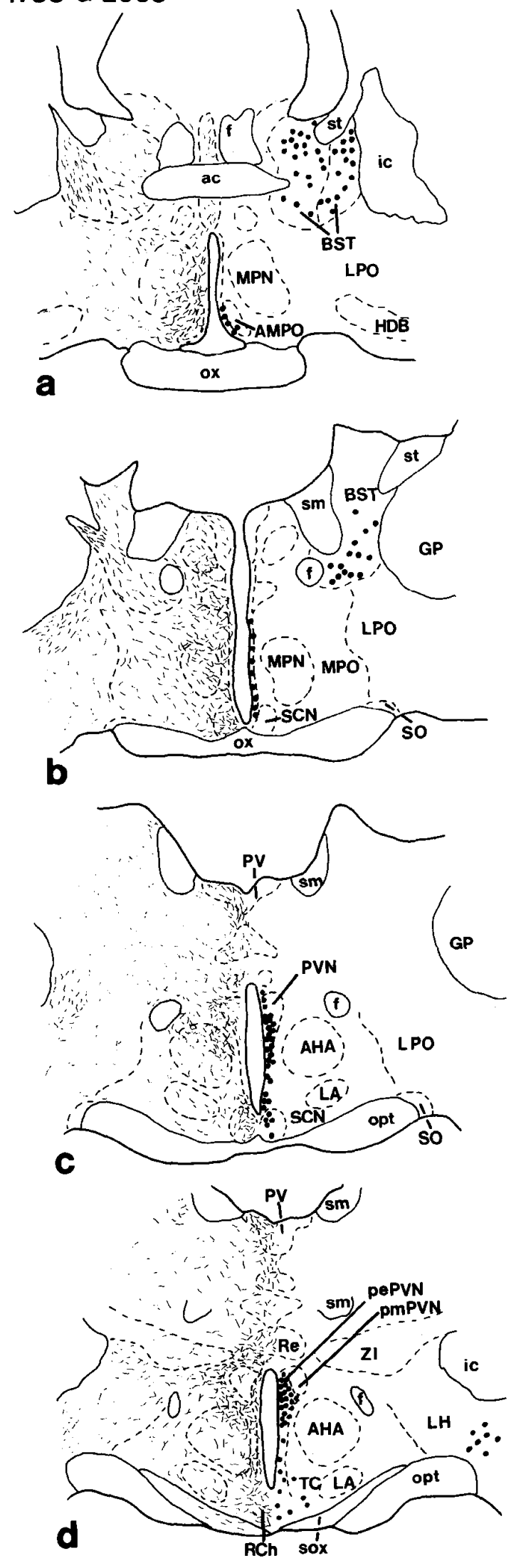

$1654 \& 4576$
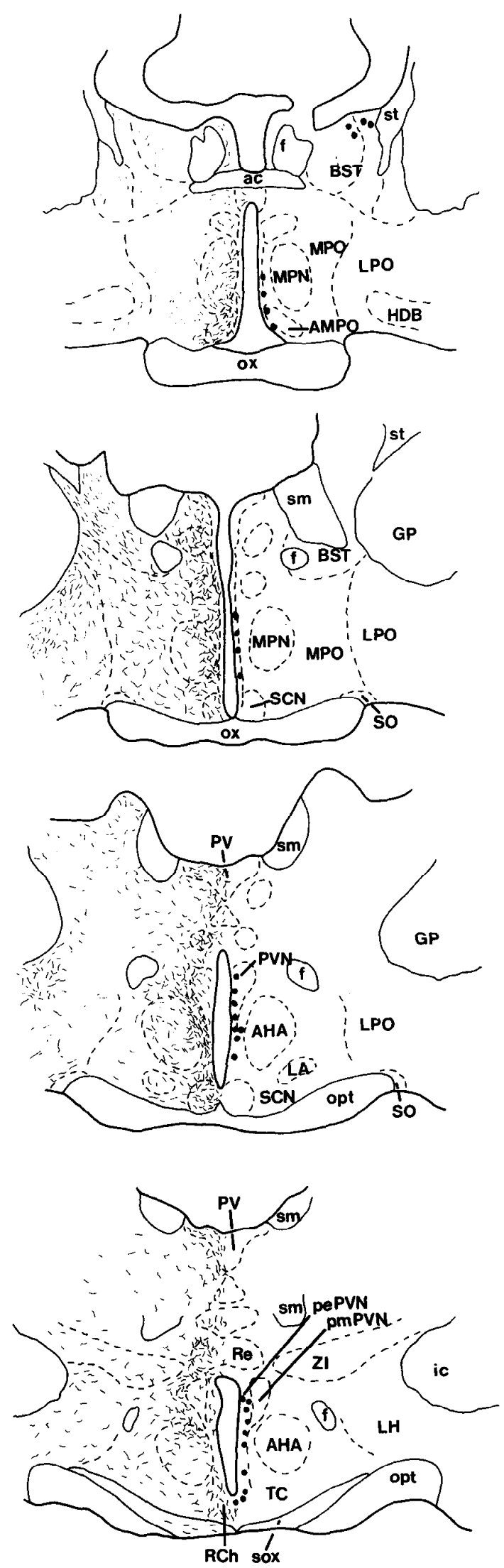


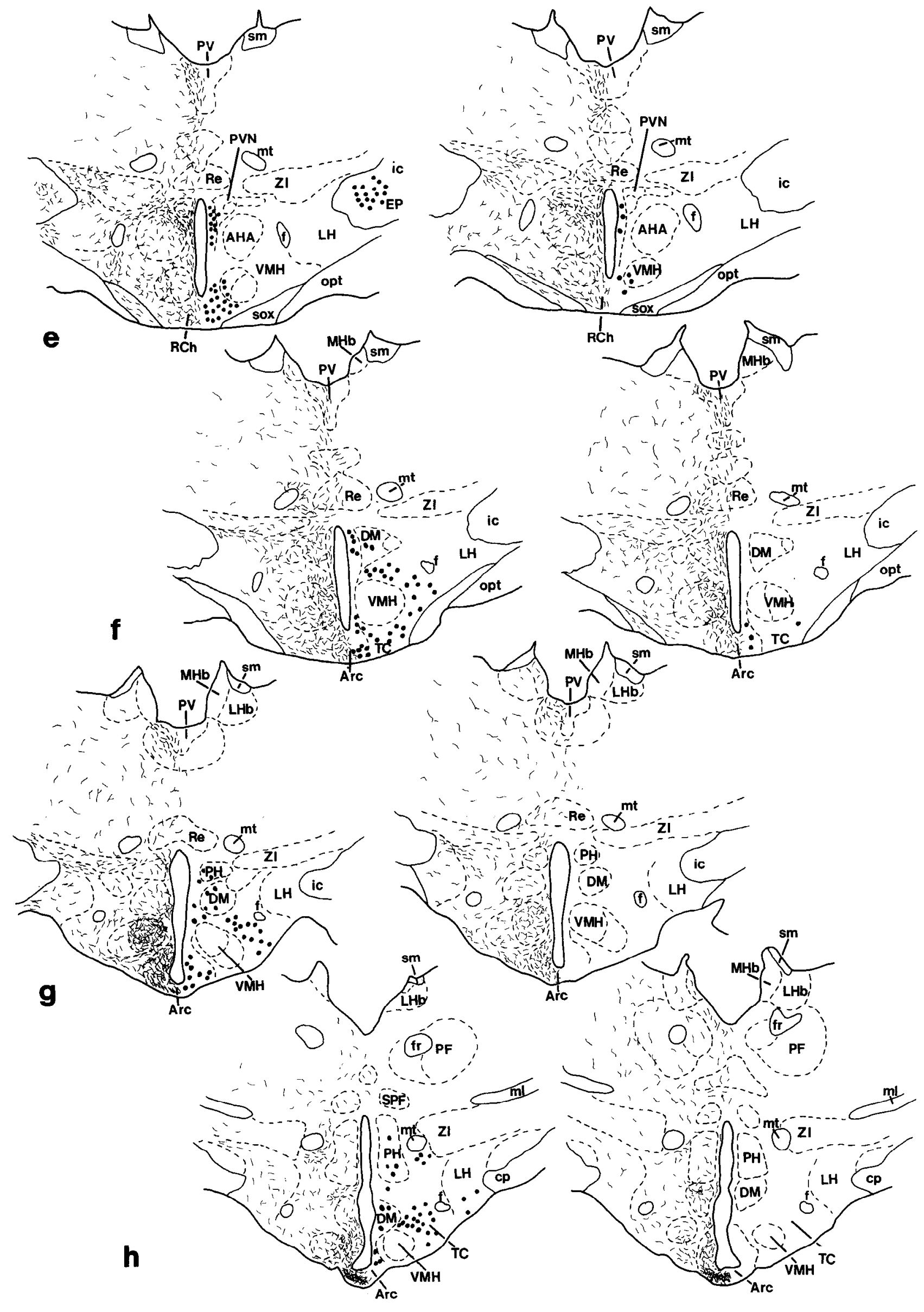




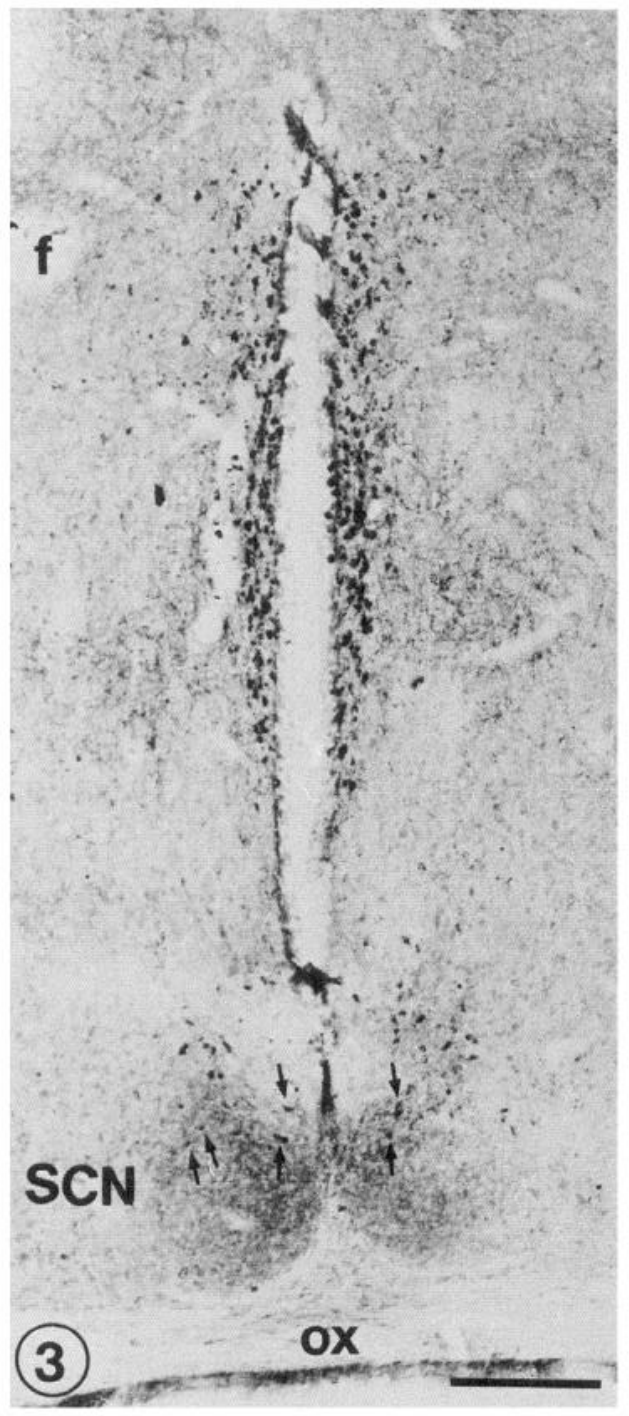

Figure 3. Low-power photomicrograph showing the periventricular area of third ventricle at the level of the suprachiasmatic nucleus $(S C N)$. A high number of immunoreactive cell bodies visualized with antiserum 2098 is seen in the dorsal two-thirds of the periventricular area. A few immunoreactive cell bodies are seen in the dorsomedial part of the suprachiasmatic nucleus (arrows). For other abbreviations, see Appendix. Scale bar, $200 \mu \mathrm{m}$.

were cryoprotected in a $30 \%$ sucrose solution in KPBS (pH 7.4) for 2 $\mathrm{d}$ before either serial sagittal sections $(20 \mu \mathrm{m})$ or serial frontal sections $(40 \mu \mathrm{m})$ were cut on a cryostat. The sections were rinsed for $2 \times 10$ min in KPBS and then incubated at $4^{\circ} \mathrm{C}$ for $24 \mathrm{hr}$ in primary antiserum. After this incubation, the sections were washed for $3 \times 10 \mathrm{~min}$ in KPBS (pH 7.4) plus $0.1 \%$ TX-100 and $0.3 \%$ BSA (KPBS-BT) followed by incubation with biotinylated swine anti-rabbit IgG (E353, Dakopatts, Copenhagen, Denmark) diluted 1:200 in KPBS-BT at room temperature for $60 \mathrm{~min}$. The sections were then washed for $3 \times 10 \mathrm{~min}$ in KPBSBT and finally incubated at room temperature for $60 \mathrm{~min}$ in avidinbiotin-conjugated horseradish peroxidase (K377, Dakopatts) diluted 1:1000 in KPBS-BT. After a wash for $10 \mathrm{~min}$ in KPBS-BT and for 2 $\times 10 \mathrm{~min}$ in $0.05 \mathrm{M}$ Tris- $\mathrm{HCl}$ buffer $(\mathrm{pH} \mathrm{7.6})$, the sections were reacted for peroxidatic activity by incubation in the latter buffer containing $0.025 \% 3,3^{\prime}$-diaminobenzidine (DAB) and $0.003 \% \mathrm{H}_{2} \mathrm{O}_{2}$ for $20 \mathrm{~min}$. After washing for $2 \times 10 \mathrm{~min}$ in distilled water, sections were mounted on gelatin-subbed slides, dehydrated in a series of ethanol, and coverslipped. For topographical studies a similar series of sections was counterstained in thionine.
Immunohistochemical controls. In order to elucidate possible crossreactivity with various antigens including the synthetic peptide the antiserum was raised against, antisera were preabsorbed for $24 \mathrm{hr}$ with 2 $\mu \mathrm{M}$ of each of the following four peptides: SS-14, SS-28, SS-28(1-12), and pro-SS(20-36).

In situ hybridization. The animals were fixed and cryoprotected as above. Brain sections $(20 \mu \mathrm{m})$ were cut in the frontal plane and placed on glass slides prerinsed in a $2 \%$ solution of RNase-removing agent AbSolve@ (DuPont, Wilmington, DE). The sections were delipidated in a series of graded alcohol and rehydrated in diethylpyrocarbonate (DEPC)-containing sterile water (DEPC- $\left.\mathrm{H}_{2} \mathrm{O}\right)$. The sections were then incubated in $1 \mathrm{mg} / \mathrm{ml}$ Proteinase $\mathrm{K}$ (Sigma) in $0.01 \mathrm{M}$ Tris- $\mathrm{HCl}$ buffer (pH 7.4, with $0.05 \mathrm{mM} \mathrm{CaCl}_{2}$ ) for $15 \mathrm{~min}$ at $37^{\circ} \mathrm{C}$ and rinsed for $30 \mathrm{~min}$ in $2 \times$ SSC (300 mm sodium chloride, $30 \mathrm{~mm}$ sodium citrate, $\mathrm{pH} 7.0$ ). The sections were thereafter preincubated in the hybridization buffer [1.0 gm dextran sulfate; $351 \mathrm{mg} \mathrm{NaCl} ; 50 \mathrm{ml} 2$ м Tris- $\mathrm{HCl}, \mathrm{pH} 7.4 ; 2$ $\mathrm{ml} 50 \times$ Denhardt's solution; $20 \mathrm{ml} 0.5 \mathrm{~m}$ EDTA; $5 \mathrm{mg}$ yeast $t$ RNA (Sigma); $5 \mathrm{mg}$ salmon testes DNA (Sigma); $5 \mathrm{ml}$ deionized formamide, and $2.93 \mathrm{ml}$ DEPC- $\mathrm{H}_{2} \mathrm{O}$ ] for $1 \mathrm{hr}$ at $27^{\circ} \mathrm{C}$. The hybridization was performed by adding the ${ }^{35} \mathrm{~S}$-labeled pro-somatostatin oligonucleotide probe (somatostatin antisense probe; DuPont, code NEP-203) to the hybridization buffer to a concentration of $0.67 \mathrm{pM}(1.3 \times 10 \mathrm{cpm} / \mathrm{section})$ at $27^{\circ} \mathrm{C}$ and incubated overnight. After hybridization, the sections were rinsed for $30 \mathrm{~min}$ in $1 \times \mathrm{SSC}$ at $27^{\circ} \mathrm{C}$ followed by a rinse in $1 \times \mathrm{SSC}$ at room temperature. The slides were dried under stream of cold air and covered by Ilford $\mathrm{K} 2$ photographic emulsion diluted with distilled water $1: 1$ and placed in light-safe boxes for exposure at $4^{\circ} \mathrm{C}$. After $7-14 \mathrm{~d}$ of exposure, the autoradiographs were developed for $3 \mathrm{~min}$ at $20^{\circ} \mathrm{C}$ in Kodak D-19, fixed in 30\% thiosulfate, counterstained with cresyl violet, dehydrated in a series of alcohol, and coverslipped with Depex ${ }^{\star}$. A separate set of sections was treated with RNase $\left(1 \mu \mathrm{g} / \mathrm{ml}, 1 \mathrm{hr}\right.$ at $\left.37^{\circ} \mathrm{C}\right)$ before hybridization. A further control was carried out by omitting the oligonucleotide probe during hybridization, although all other conditions were maintained constant.

Cell counting. To quantify the immunohistochemically labeled sections and the labeled emulsion autoradiograms, the number of labeled cells was counted manually in selected areas. The counting was done twice and the procedure was performed bilaterally on corresponding sections from two different experiments. The recording of neurons was facilitated by positioning an ocular grid over the area and systematically counting the labeled neurons within each row of the grid.

Chromatographic analysis. Fifty adult male Mongolian gerbils were killed by decapitation, and the brains and pituitaries were rapidly removed. Acid ethanol extracts were prepared according to method II of Newgard and Holst (1981). Briefly, the frozen tissue was homogenized in 4 vol of acid ethanol at $-20^{\circ} \mathrm{C}$ and centrifuged. Five volumes of icecold diethyl ether were added to the supernatant, and the aqueous proteinaceous phase was isolated at $-50^{\circ} \mathrm{C}$. The resulting precipitate was dissolved in $1 \mathrm{~m}$ urea, buffered to $\mathrm{pH} 5.0$, and applied to a $16 \times 1000$ $\mathrm{mm}(\mathrm{K} 16 / 100)$ column packed with Sephadex G50 fine grade (Pharmacia, Uppsala, Sweden), equilibrated, and eluted, at a flow rate of 300 $\mathrm{ml} / \mathrm{min}$ at $4^{\circ} \mathrm{C}$, with an albumin-containing phosphate assay buffer. Elution positions are referred to by their coefficient of distribution, $K_{D}$ $=\left(V_{e}-V_{o}\right) / V_{i}$, where $V_{o}$ is the elution volume of a completely excluded substance; $V_{i}$, the available inner volume, determined as the difference between the elution volumes of ${ }^{125} \mathrm{I}$-labeled albumin $\left(V_{o}\right)$ and ${ }^{27} \mathrm{NaCl}$, both added to the sample for internal calibration; and $V_{e}$, the elution volume of the substance in question. In separate experiments, gel filtrations were performed with synthetic somatostatin-14, synthetic somatostatin-28(1-12), synthetic somatostatin-28, and the natural porcine pro-somatostatin 1-64 (Bersani et al., 1989). Eluted fractions were assayed with radioimmunoassay based on antiserum codes 2098, 4576, and 1758 as described previously (Holst et al., 1988).

\section{Results}

Differences in the localization of stained neurons among the hypothalamic nuclei were observed. Therefore, hypothalamic immunoreactivities are referred to as prosomatostatin(20-36)like immunoreactivity (pro-SS-LI), somatostatin-28(1-12)-like immunoreactivity [SS-28(1-12)-LI] somatostatin-28-like immunoreactivity (SS-28-LI), and somatostatin-14-like immunoreactivity (SS-14-LI), respectively. In those areas where no difference in distribution of various immunoreactivities was 


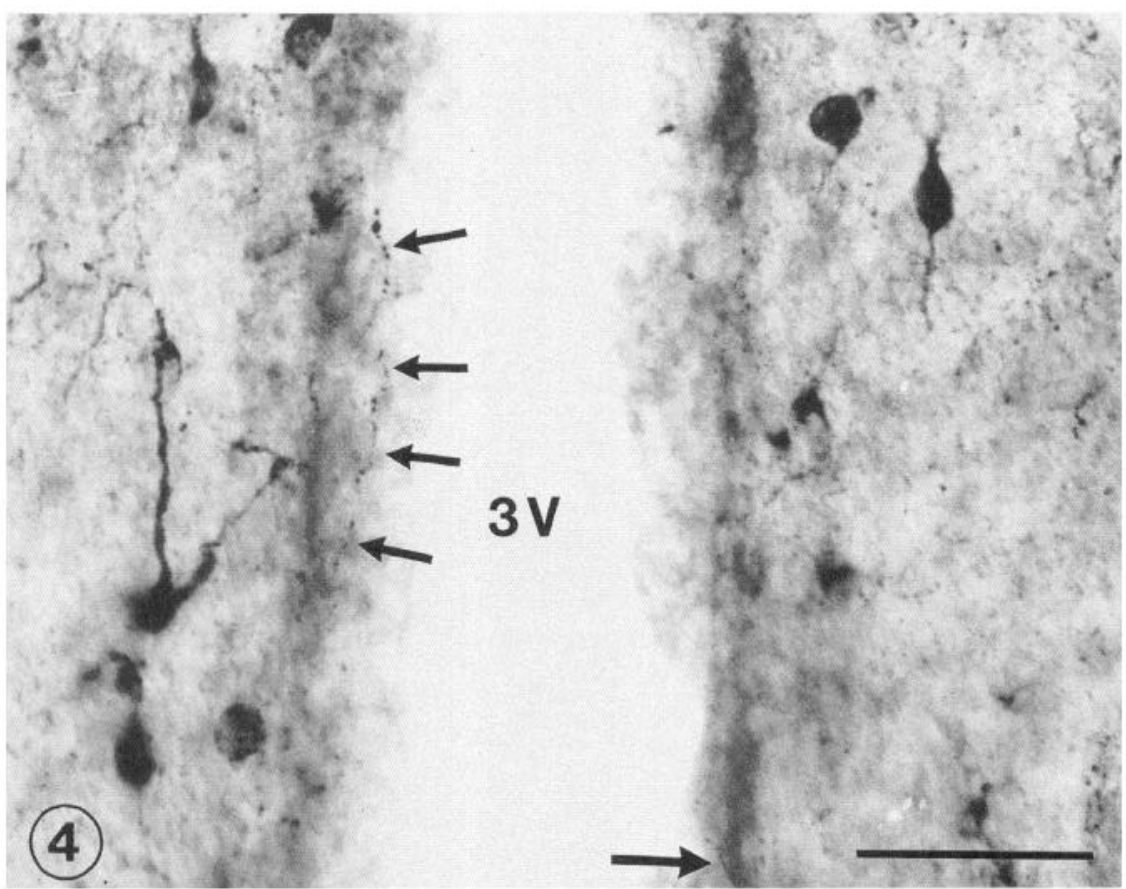

Figure 4. High-power photomicrograph from the rostral periventricular area of the third ventricle $(3 \mathrm{~V})$. Small ovoid, and medium-sized elongated immunoreactive cell bodies visualized with antiserum 1758 are seen in the periventricular area. Intraependymally situated nerve fibers endowed with boutons en passant are indicated with arrows. Scale bar, $50 \mu \mathrm{m}$. present, the immunoreactive elements are more conveniently referred to as somatostatin-like immunoreactivity (SRIF-LI).

Within the preoptic area and hypothalamus, immunoreactive cell bodies and nerve fibers were observed with all four antisera (Fig. 2). The number of immunoreactive cell bodies visualized with the various antisera differed significantly in certain areas (Table 2). Within the suprachiasmatic, the ventromedial, the dorsomedial, and the posterior hypothalamic nuclei, the retrochiasmatic area, the area of the tuber cinereum, and the caudal aspects of the lateral hypothalamic area, only pro-SS-LI and SS14-LI cell bodies were present. However, in the periventricular area, the paraventricular nucleus (PVN), and arcuate nucleus, pro-SS-LI and SS-14-LI cell bodies as well as a small number of SS-28-LI and SS-28(1-12)-LI cell bodies were observed. Within the suprachiasmatic and ventromedial nuclei and the retro-

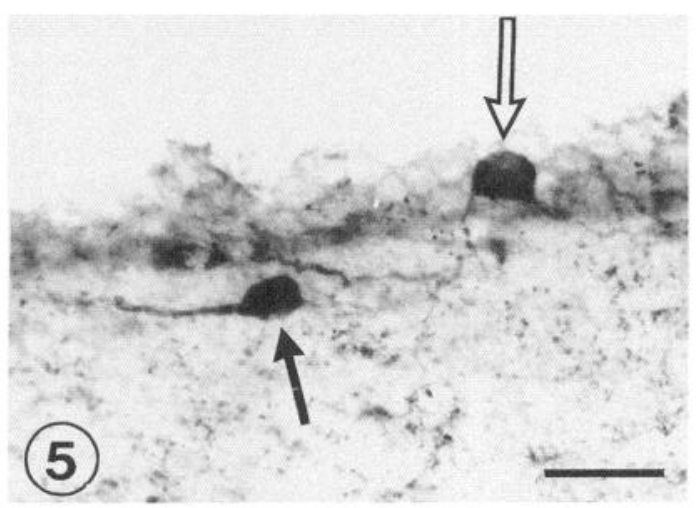

Figure 5. High-power photomicrograph showing two SS-14-LI cell bodies in the periventricular area of the third ventricle. One cell body is apparently intraependymally situated (open arrow), whereas another is located in the neuropil of the periventricular strata (solid arrow). Scale bar, $25 \mu \mathrm{m}$. chiasmatic and the lateral hypothalamic areas, the density of pro-SS-LI and SS-14-LI fibers was higher than the density of SS-28-LI and SS-28(1-12)-LI fibers.

\section{$S S$-immunoreactive neurons in the preoptic area and hypothalamus}

Periventricular cell group. Small- to medium-sized immunoreactive perikarya were located periventricularily from the supraoptic to the mammillary recess (Figs. 2, 3; see also 7, 8). The cells were predominantly situated close to the ependyma of the third ventricle, and few immunoreactive cellular processes endowed with varcosities penetrated the ependyma (Fig. 4). Occasionally, an intraependymally situated immunoreactive cell body was observed (Figs. 5, 6). In the preoptic area, the immunoreactive cell bodies were restricted to the ventral aspect

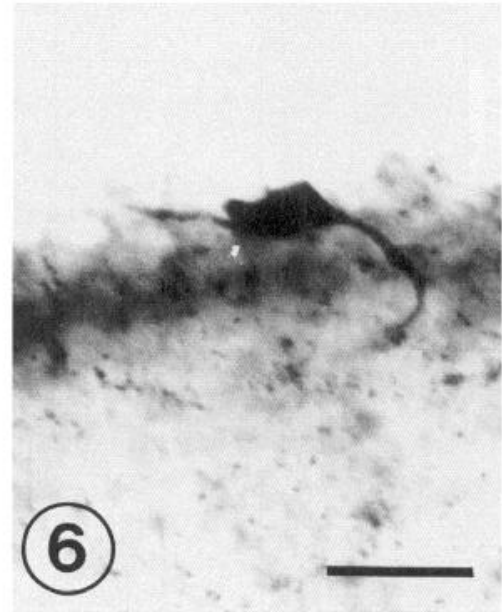

Figure 6. High-power photomicrograph of an intraependymally situated pro-SS-LI cell body. Scale bar, $25 \mu \mathrm{m}$. 

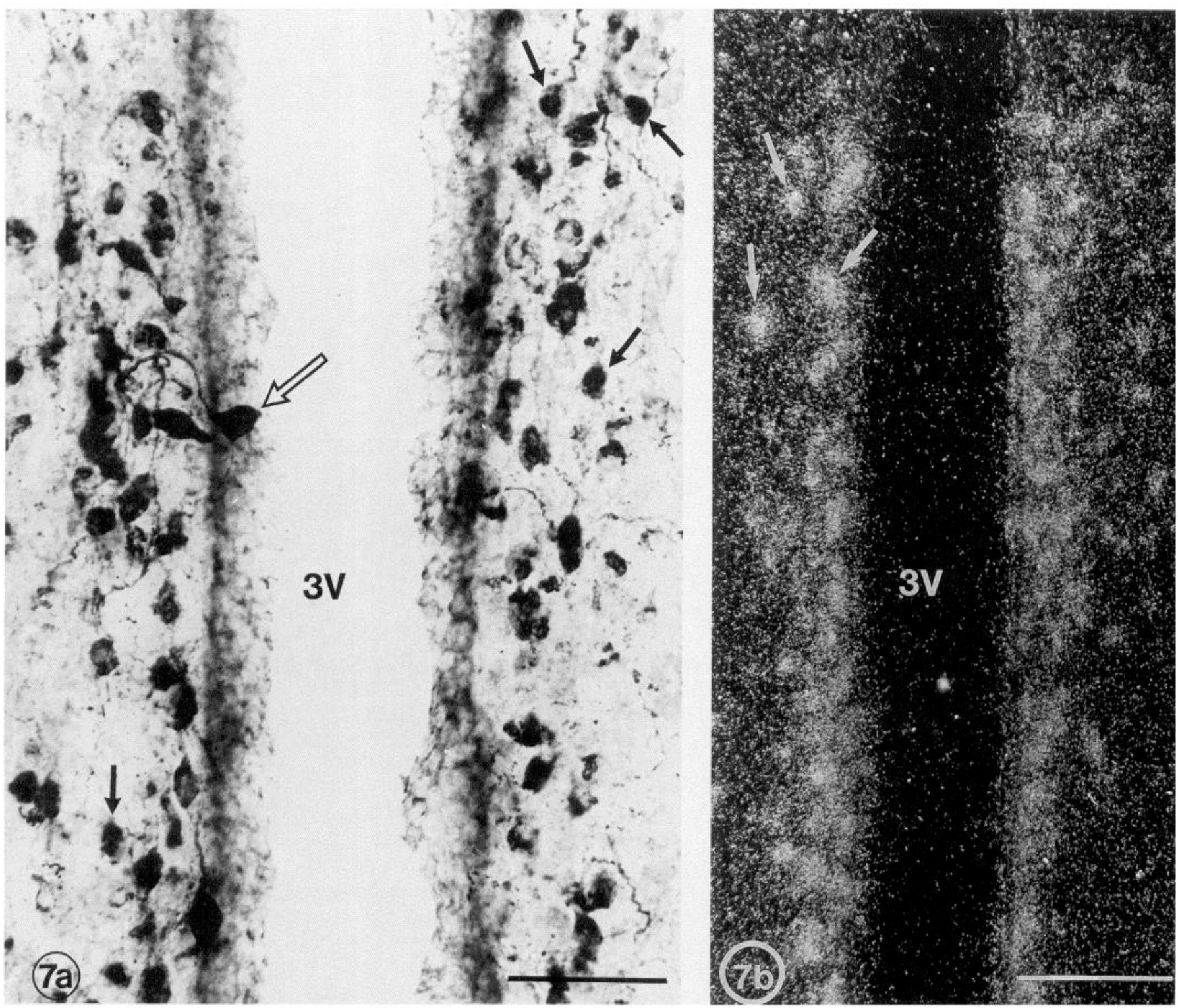

Figure 7. High-power photomicrographs of the periventricular subnucleus of the PVN. In $a$, a large number of SS-14-LI cell bodies is seen. A single intraependymally situated cell body can be seen (open arrow). The predominant type of immunoreactive cell body is small and ovoid (solid arrows), whereas only few medium-sized and elongated cell bodies are seen. In $b$, the in situ hybridization histochemical signal shows a high number of SS mRNA-containing cell bodies. A high grain density is seen over individually labeled cell bodies (arrows). $3 \mathrm{~V}$, third ventricle. Scale bars, $50 \mu \mathrm{m}$.

of the periventricular area (Fig. $2 a$ ). At the rostral part of the suprachiasmatic nucleus, the immunoreactive periventricular cell bodies were observed in the full ventrodorsal extent of the periventricular area (Fig. $2 b$ ). Farther caudally, at the level of the paraventricular nucleus, the periventricular cells were encountered as distinct dorsal and ventral groups of perikarya (Fig. $2 c$ ).

The dorsal group was continuous with immunoreactive cell bodies in the periventricular and medial parvicellular subnuclei of the PVN. A very high density of immunoreactive perikarya was observed in the periventricular parvocellular subnucleus (Figs. 3, 7), whereas fewer were observed in the medial parvocellular subnucleus. Furthermore, only cells displaying proSS-LI and SS-14-LI were observed in the medial parvicellular subnucleus, whereas cells displaying SS-28-LI and SS-28(1-12)-
LI were strictly confined to the periventricular parvicellular subnucleus (Fig. $2 d, e$ ). Caudal to the PVN, the number of labeled cells in the dorsal periventricular cell group decreased significantly (Fig. 2f). The ventral periventricular group of perikarya was located medially to the anterior hypothalamic area and extended from the suprachiasmatic nucleus via the retrochiasmatic area into the arcuate nucleus.

Suprachiasmatic nucleus. In the suprachiasmatic nucleus, sparse and faintly labeled immunoreactive cells were encountered in the extreme dorsomedial portion of the nucleus (Fig. 3 ). However, occasionally a labeled cell body was observed in the most lateral aspects of the ventrolateral portion.

Tuber cinereum. Within the tuber cinereum, scattered immunoreactive cells were observed in the medial portion of the ventromedial hypothalamic nucleus, the dorsomedial hypotha- 
lamic nucleus, the retrochiasmatic and perifornical areas, and the area of the tuber cinereum. In the retrochiasmatic area, immunoreactive cells were scattered throughout the area from the optic chiasm to the arcuate nucleus (Fig. 9). This cell group merged with the periventricular cell group and laterally with the immunoreactive cells encountered in the area of the tuber cinereum (Fig. 10). The immunoreactive cell bodies encountered in lateral aspect of the area of the tuber cinereum were mediumsized and elongated (Fig. 11), whereas those encountered in the medial aspect were small and rounded (Fig. 13). Occasionally, pro-SS-LI and SS-14-LI cells were encountered in the rostral portion of the ventromedial nucleus, whereas the nucleus was devoid of immunoreactive cell bodies at more caudal levels. At the midlevel of the ventromedial nucleus, the area of the tuber cinereum contained labeled cells surrounding the nucleus laterally from the dorsolateral part to the ventrolateral part (Fig. $2 f, g$ ). In particular, the region intervening between the ventromedial and the dorsomedial nuclei contained a high number of immunoreactive cell bodies (Fig. 12).

Dorsal and lateral region (caudal parts). Within the dorsal hypothalamic area, a low number of scattered immunoreactive cells were located ventral to the mammillothalamic tract and ventrolateral to the thalamic reuniens nucleus (Fig. $2 g$ ). Within the lateral hypothalamic area, scattered immunoreactive cells were encountered in its ventromedial and caudal parts (Fig. $2 h$ ).

Arcuate nucleus. The arcuate nucleus contained a moderate number of immunoreactive cell bodies with a morphology different from the SRIF-LI cells located in the periventricular area. The small cell bodies of the arcuate nucleus were unevenly stained (Figs. 14-16). It should be emphasized that within the caudal part of the nucleus, only cell bodies displaying pro-SSLI and SS-14-LI were observed. In the rostral part of the arcuate nucleus, the pro-SS-LI and SS-14-LI cell bodies were more numerous than the SS-28-LI and SS-28(1-12)-LI cell bodies and were continuous laterally with loosely arranged immunoreactive cells in the area of the tuber cinereum.

\section{$S S$-immunoreactive nerve fibers in the preoptic area and hypothalamus}

In addition to the areas containing immunoreactive perikarya, several areas contained immunoreactive nerve fibers. In general,

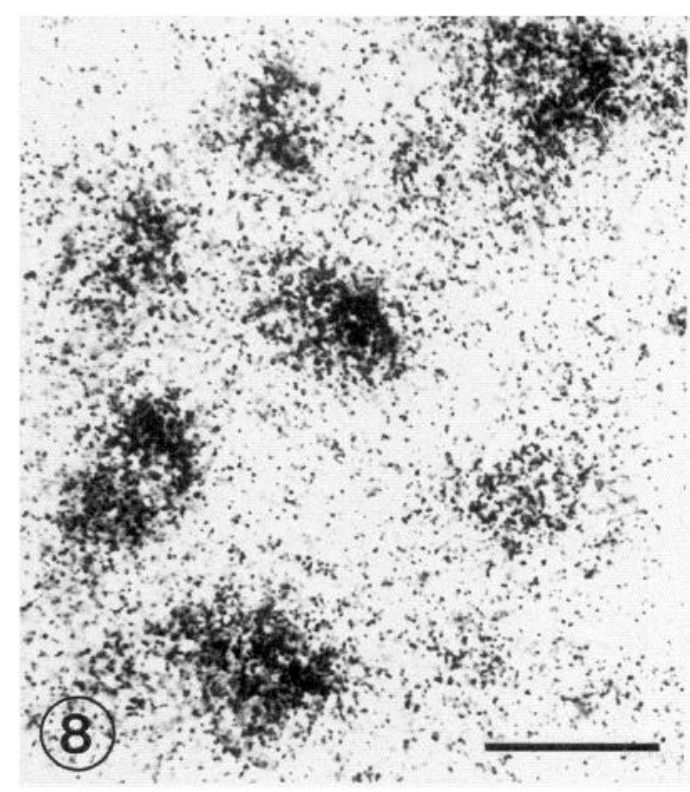

Figure 8. High-power photomicrograph from the periventricular area of the third ventricle. A high density of grains is seen overlayering individual cell bodies, showing in situ hybridization signal for SS mRNA. Scale bar, $10 \mu \mathrm{m}$.

fibers displayed with all employed antisera were of fine caliber with a beaded appearance.

The periventricular area contained a dense plexus of immunoreactive fibers, some of which could be followed into the ependyma, but intraventricular nerve fibers were never found. In the preoptic area, extensive plexuses of fibers were observed in the organum vasculosum laminae terminalis (OVLT), the anterior ventral preoptic and the medial preoptic nuclei, and the medial preoptic area (Fig. $2 a, b$ ). In contrast, the lateral preoptic area contained a labeled fiber plexus of low to moderate density.

The anterior hypothalamic area was only sparsely innervated by immunoreactive fibers (Fig. $2 c-e$ ), whereas the suprachiasmatic nucleus exhibited a high density of immunoreactive fibers (Fig. 3). The retrochiasmatic area contained a plexus of moderate density of immunoreactive fibers (Fig. $2 d, e$ ). The mag-

\begin{tabular}{|c|c|c|c|c|c|}
\hline $\begin{array}{l}\text { Visual- } \\
\text { ization } \\
\text { method }\end{array}$ & $\begin{array}{l}\text { Paraven- } \\
\text { tricular } \\
\text { nucleus }^{a}\end{array}$ & $\begin{array}{l}\text { Retro- } \\
\text { chiasmatic } \\
\text { area }^{a}\end{array}$ & $\begin{array}{l}\text { Arcuate } \\
\text { nucleus }^{b}\end{array}$ & $\begin{array}{l}\text { Peri- } \\
\text { ventricular } \\
\text { nucleus }^{b}\end{array}$ & $\begin{array}{l}\text { Supra- } \\
\text { chiasmatic } \\
\text { nucleus }^{b}\end{array}$ \\
\hline 1758 & $75.25 \pm 13.7$ & $108.2 \pm 9.9$ & $46.50 \pm 9.1$ & $9.75 \pm 2.2$ & $23.00 \pm 2.4$ \\
\hline 2098 & $82.25 \pm 10.4$ & $99.00 \pm 4.24$ & $47.75 \pm 2.9$ & $10.25 \pm 1.5$ & $25.25 \pm 3.9$ \\
\hline 4576 & $15.25 \pm 3.2^{c}$ & $0.25 \pm 0.5^{c}$ & $0.25 \pm 0.5^{e}$ & $0.75 \pm 0.5^{c}$ & $0.00 \pm 0^{c}$ \\
\hline 1654 & $19.25 \pm 3.0^{d}$ & $0.50 \pm 1.0^{d}$ & $0.00 \pm 0.0 r$ & $2.00 \pm 0.8^{d}$ & $1.00 \pm 1.2^{d}$ \\
\hline In situ & $78.25 \pm 8.1$ & $106.00 \pm 7.0$ & $66.75 \pm 3.8^{g}$ & $10.00 \pm 1.4$ & $22.75 \pm 3.2$ \\
\hline
\end{tabular}

Values are given as means $\pm \mathrm{SEM} ; n=4$ in all cases.

${ }^{a} p<0.05$ as determined by Friedman's test.

${ }^{b} p<0.01$ as determined by Friedman's test.

${ }^{c} p<0.05(1758,2098$, in situ vs. 4576) as determined by ANOVA.

${ }^{d} p<0.05(1758,2098$, in situ vs. 1654) as determined by ANOVA.

e $p<0.01$ (1758, 2098 vs. 4576) as determined by ANOVA.

${ }^{\prime} p<0.01(1758,2098$ vs. 1654) as determined by ANOVA.

${ }^{g} p<0.05(1758,2098$ vs. in situ $)$ as determined by ANOVA. 
Figure 9. Low-power photomicrograph of the ventral part of the gerbil hypothalamus. A large number of proSS-LI cell bodies is seen in the retrochiasmatic area and the area of the tuber cinereum. $3 V$, third ventricle. Scale bar, $200 \mu \mathrm{m}$.

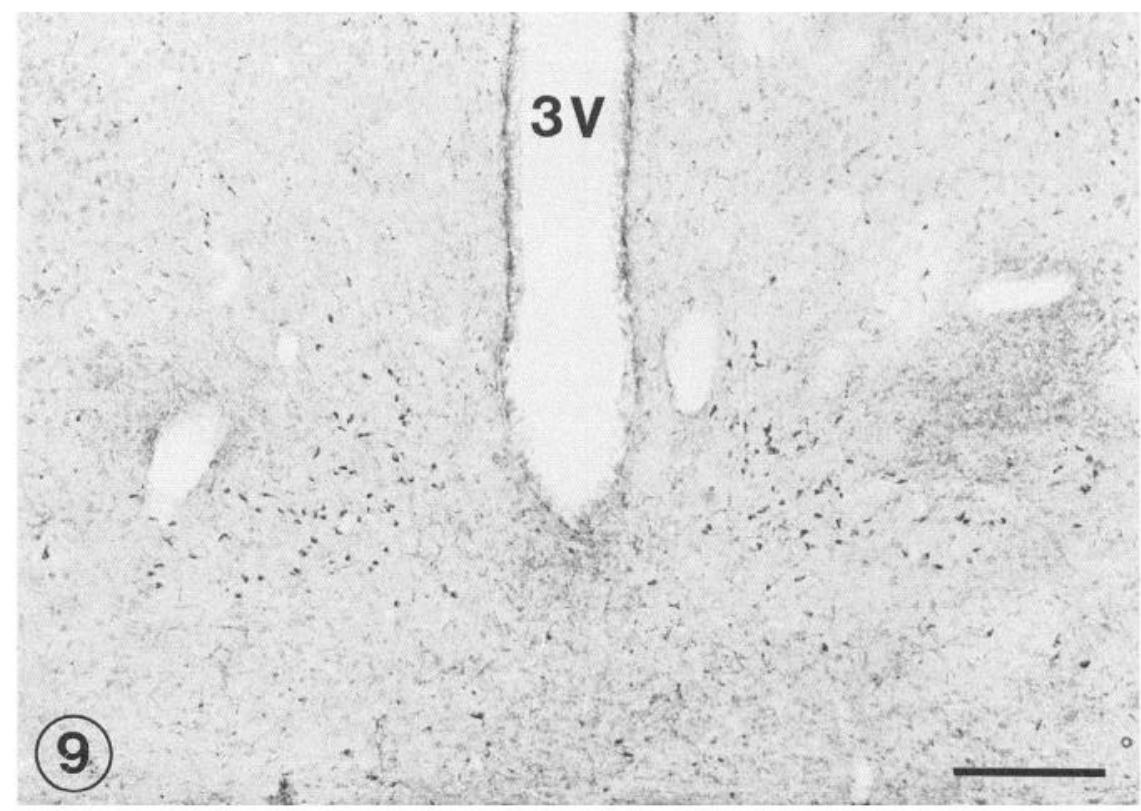

nocellular PVN and supraoptic nucleus contained plexuses of immunoreactive fibers of low density (Fig. $2 b-d$ ).

In the ventromedial and the arcuate nuclei, the highest density of immunoreactive fibers in the hypothalamus proper was encountered. Very dense pro-SS-LI and SS-14-LI fiber plexuses were observed in the medial portion of the ventromedial nucleus (Figs. 10, 12). Within the arcuate nucleus, the fiber plexus became increasingly denser when followed in direction of the median eminence.

Throughout the lateral hypothalamic area, pro-SS-LI and SS14-LI fibers were observed having a moderate to low density in the ventral aspects and a high density in the dorsal aspects close to the zona incerta, whereas only single SS-28(1-12)-LI and SS28-LI fibers were seen in this area.

\section{SS immunoreactivity in the median eminence and the posterior pituitary}

In the rostral part of the median eminence, a very high density of SRIF-LI fibers terminating in the perivascular spaces was observed. In the caudal part, the density of SRIF-LI fibers was lower (see Fig. 17a-c). Fibers originating from the rostral part of the median eminence coursed via the infundibular stalk into the posterior pituitary lobe. A very dense accumulation of SRIFLI fibers could be seen in the external zone of the median eminence. The internal zone of the median eminence contained fewer SRIF-LI elements, and individually discernible nerve fibers could be followed in a direction more or less parallel to the ventral surface of the brain via the infundibular stalk into the posterior pituitary lobe. In the rostral part of the posterior pituitary lobe, the SRIF-LI fibers spread diffusely, often to terminate in close apposition to blood vessels (see Fig. 17e). In the central part of the posterior pituitary lobe, SRIF-LI fibers were sparsely distributed in close proximity to the intermediate lobe.

\section{In situ hybridization}

In order to investigate whether cellular labeling revealed with the immunohistochemical staining was accompanied by an in-
Figure 10. Low-power photomicrograph of the ventral part of the gerbil hypothalamus at a level $240 \mu \mathrm{m}$ caudal to that shown in Figure 9. A high density of pro-SS-LI fibers is seen in the medial part of the ventromedial hypothalamic nucleus $(V M H)$. A population of scattered pro-SS-LI cell bodies is seen in the area of the tuber cinereum and the lateral hypothalamic area (arrows). The boxed area is shown at higher magnification in Figure $10.3 \mathrm{~V}$, third ventricle. Scale bar, $200 \mu \mathrm{m}$.

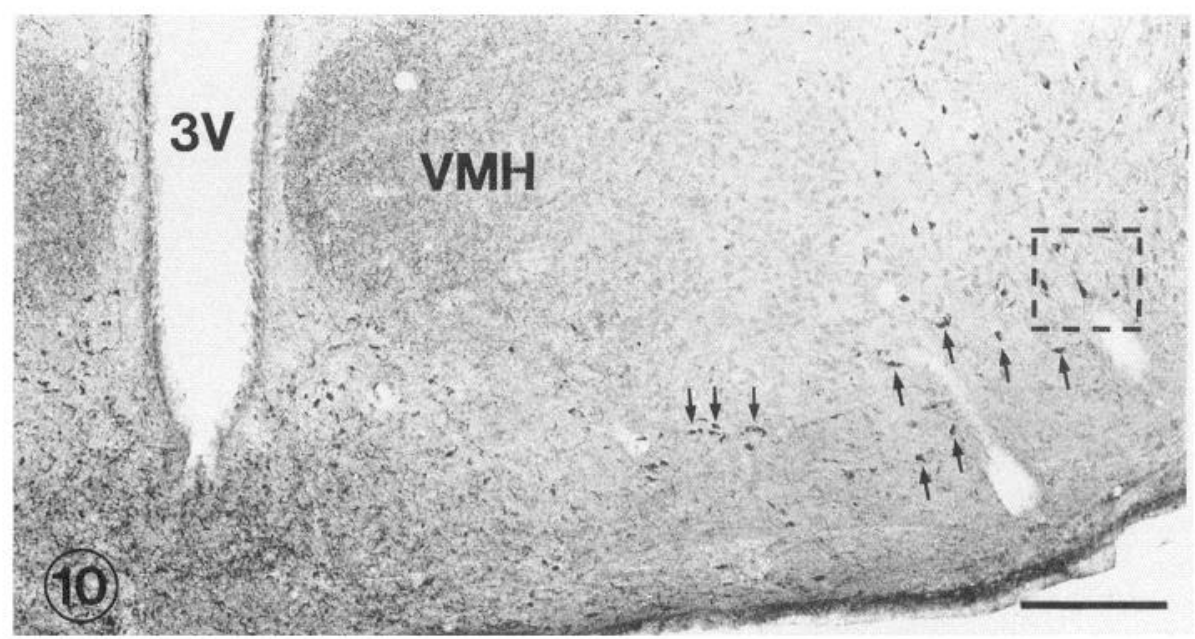




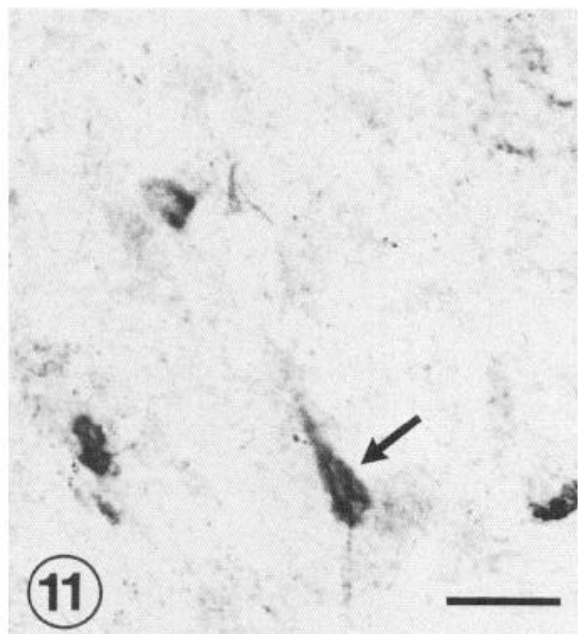

Figure 11. Higher magnification of the boxed area in Figure 10. A large triangular cell body is seen in the lateral hypothalamic area (arrow). Scale bar, $25 \mu \mathrm{m}$.

tracellular content of pro-SS mRNA, we performed in situ hybridization histochemistry on gerbil brain sections. A clear correspondence between the distribution of perikarya containing SS hybridization signal and SS was detected. Hybridization signal produced with the oligonucleotide probe was found in perikarya in all areas throughout the preoptic area and hypothalamus that contained neuronal somata displaying pro-SS-LI and SS-14-LI. Generally, the number of cell bodies revealed by in situ hybridization corresponded to that revealed by immunohistochemistry (Table 2). The densest hybridization signal in the hypothalamus was found in the periventricular cell group (Figs. $7 b, 8)$. A general correspondence between the number of grains

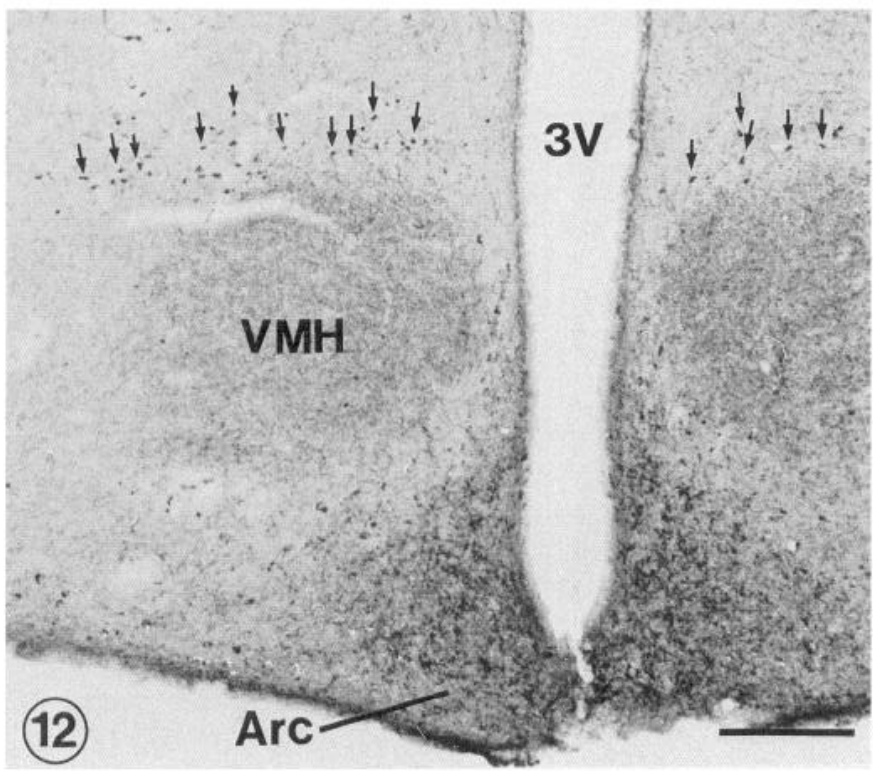

Figure 12. Low-power photomicrograph of the ventral part of the gerbil hypothalamus at a level $240 \mu \mathrm{m}$ caudal to that shown in Figure 10. A high density of pro-SS-LI cell bodies and nerve fibers is seen in the arcuate nucleus $(A r c)$. Dorsal to the ventromedial hypothalamic nucleus $(V M H)$, many pro-SS-LI cell bodies are seen in the area of the tuber cinereum (arrows). $3 V$, third ventricle. Scale bar, $200 \mu \mathrm{m}$.

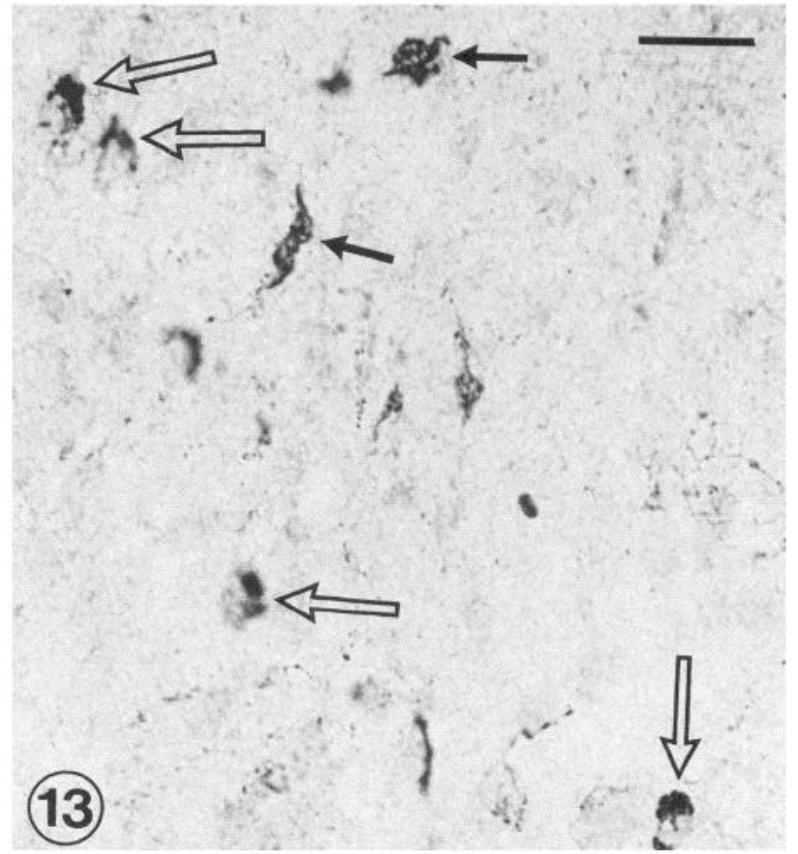

Figure 13. High-power photomicrograph of SS-14-LI cell bodies in the area of the tuber cinereum lying dorsal to the VMH. In some of the cell bodies, the immunoreactive material is apparently distributed throughout the cytoplasma (solid arrows). However, in other cell bodies, the immunoreactive material is confined to only a part of the cellular extent (open arrows). Scale bar, $25 \mu \mathrm{m}$.

overlayering individual cell bodies and the intensity of the immunohistochemical labeling was observed (Fig. 7). However, within the arcuate nucleus, the number of pro-SS-LI and SS14-LI cell bodies was about $80 \%$ of the number of cell bodies containing SS mRNA as revealed by in situ hybridization (Table 2). Furthermore, in the arcuate nucleus the individual neuronal somata were visualized with a very dense in situ hybridization

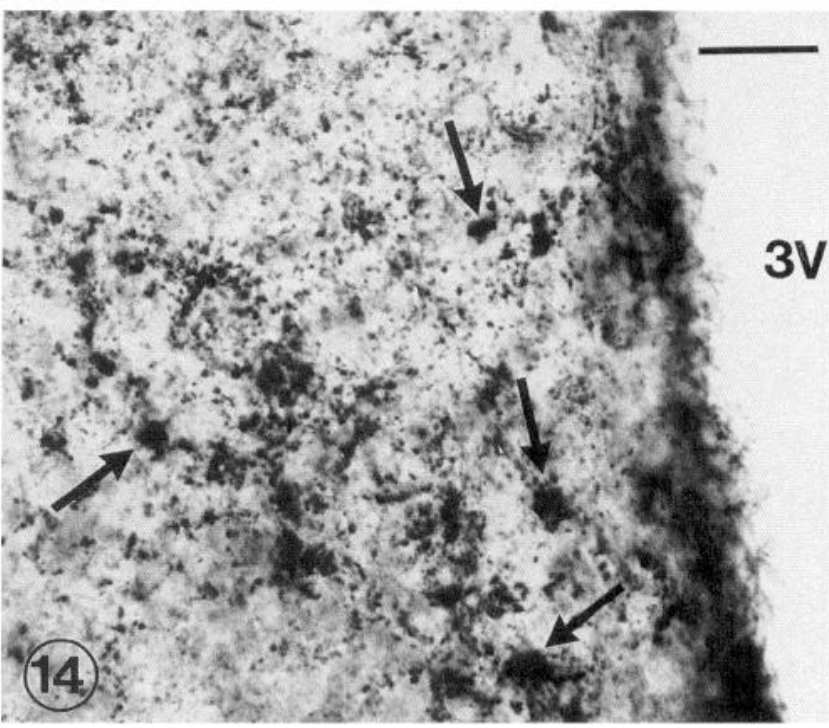

Figure 14. High-power photomicrograph of the arcuate nucleus. A moderate number of unevenly stained SS-14-LI cell bodies (arrows) and a high density of immunoreactive fibers is seen. $3 \mathrm{~V}$, third ventricle. Scale bar, $25 \mu \mathrm{m}$. 


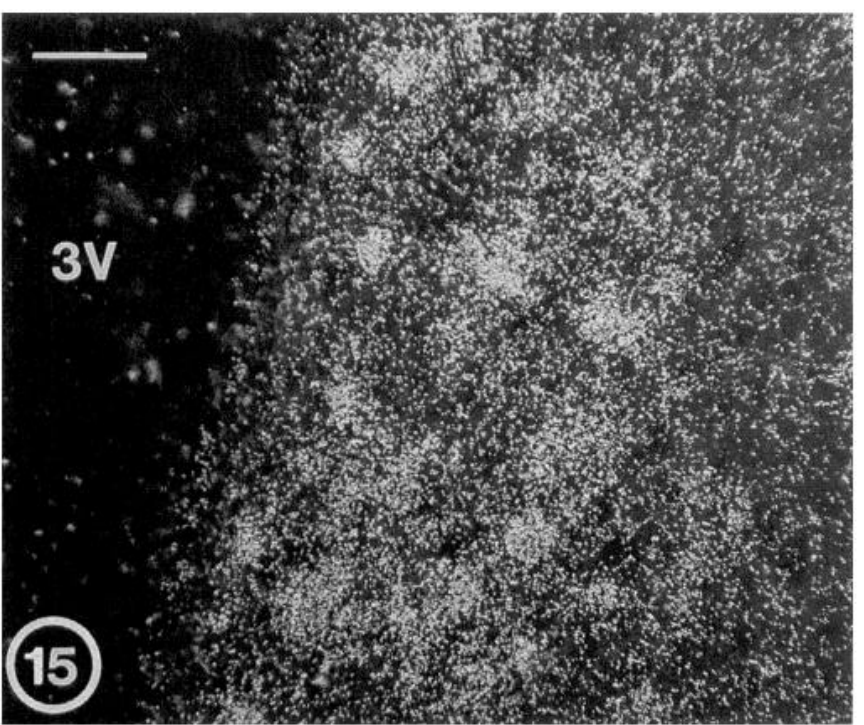

Figure 15. High-power photomicrograph of the arcuate nucleus. A high density of grains is seen over cell bodies histochemically visualized by in situ hybridization to SS mRNA. $3 V$, third ventricle. Scale bar, 25 $\mu \mathrm{m}$.

signal (Figs. 14-16), whereas they displayed a faint pro-SS-LI and SS-14-LI labeling.

\section{Gel filtration}

The combined gel filtrations and radioimmunoassays of the tissue extract from gerbil hypothalami and posterior pituitary lobes clearly demonstrate the presence of two large and several smaller molecular forms of the pro-SS molecule. The chromatographic data are presented in Figure 18.

From the hypothalamus, equimolar amounts of peptides coeluting with genuine pro-SS (1-76), pro-SS(1-64), and synthetic SS-14 were extracted. Much lower quantities of peptides coelut- ing with synthetic SS-28 and SS-28(1-12) were present in the hypothalamic extracts. The peak value of the hypothalamic SS14 elution profile corresponds to $3000 \mathrm{pmol} / \mathrm{gm}$ wet weight tissue.

The immunoreactive elution profiles of extracts from posterior pituitary lobes differed from those of hypothalamic extracts. The predominant molecular species of the pro-SS molecule coeluted with synthetic SS-28(1-12), whereas the molecular species coeluting with genuine pro-SS(1-76) was absent. The majority of large molecular fragments recognized with the 2098 antiserum coeluted with genuine pro-SS(1-64). Equimolar amounts of peptides coeluting with synthetic SS-28 and SS-14, respectively, were apparently present in extracts from posterior pituitary lobes.

\section{Discussion}

The present study represents the first attempt to describe the anatomical distribution and molecular nature of pro-SS and its processed fragments pro-SS(1-64), pro-SS(1-76), SS-14, SS-28, and SS-28(1-12) in the preoptic area, hypothalamus, and pituitary in a mammalian species by means of immunohistochemistry and gel chromatography. Additionally, the localization of pro-SS mRNA was studied in the same areas.

The localization of somatostatinergic cell bodies in the gerbil hypothalamus is largely consistent with earlier immunohistochemical observations from other mammalian species performed with antisera against SS-14 (Krisch, 1978; Dierickx and Vandesande, 1979; Hoffman and Hayes, 1979; Bennett-Clarke et al., 1980; Papadopoulos et al., 1986). Furthermore, the distribution of somatostatinergic cell bodies revealed by in situ hybridization is largely consistent with that described in the rat (Fitzpatrick-McElligott et al., 1988).

The in situ hybridization histochemistry and the localization of pro-SS mRNA to individual cell bodies establish the neuronal sites of synthesis of pro-SS throughout distinct regions of the preoptic area and hypothalamus of the gerbil. Except for the
Figure 16. Medium-power photomicrograph of the arcuate nuclei of the gerbil hypothalamus. A high density of SS mRNA-containing cell bodies visualized by means of in situ hybridization histochemistry is seen in the nuclei. Individually labeled cell bodies are easily seen as a dense accumulation of grains (arrows). For abbreviations, see Appendix. Scale bar, $100 \mu \mathrm{m}$.

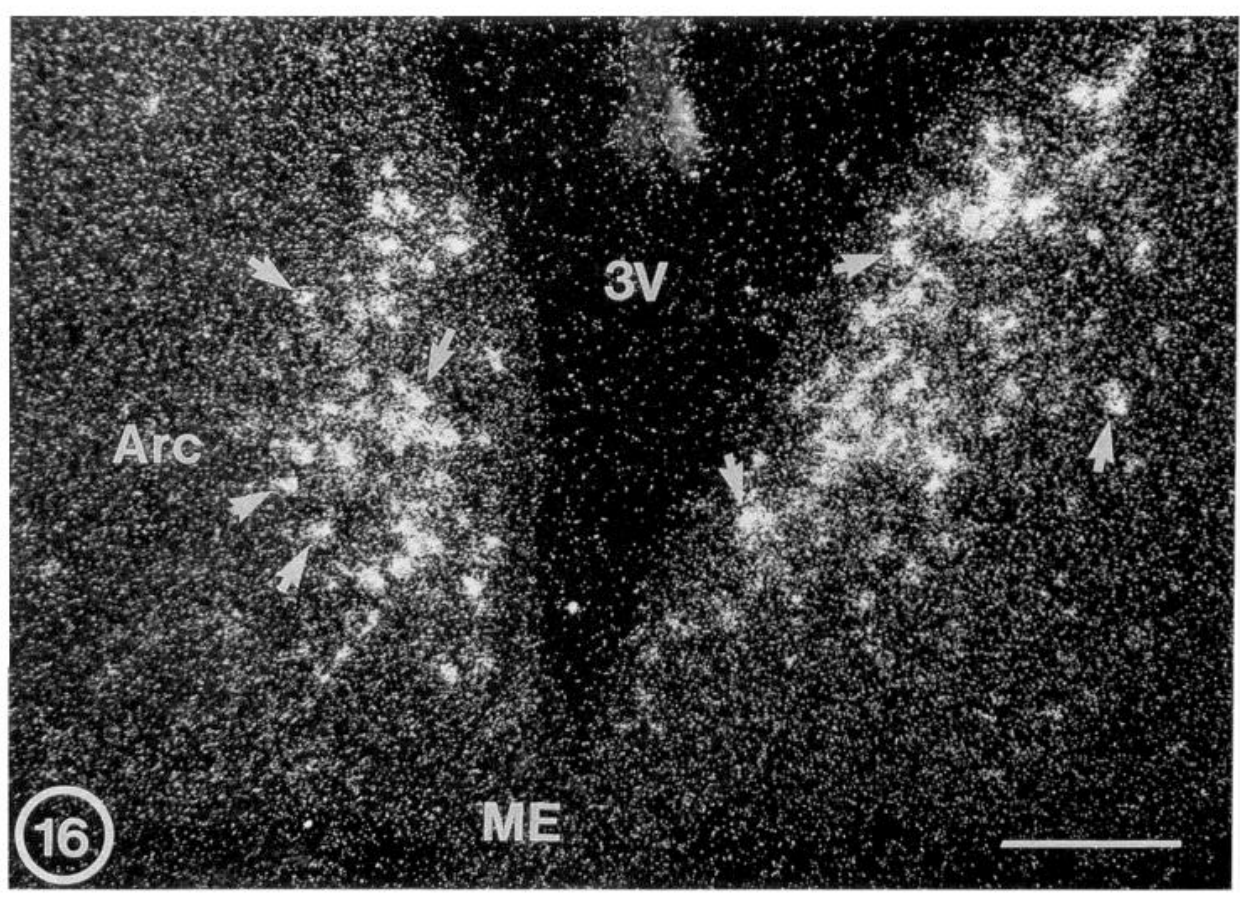



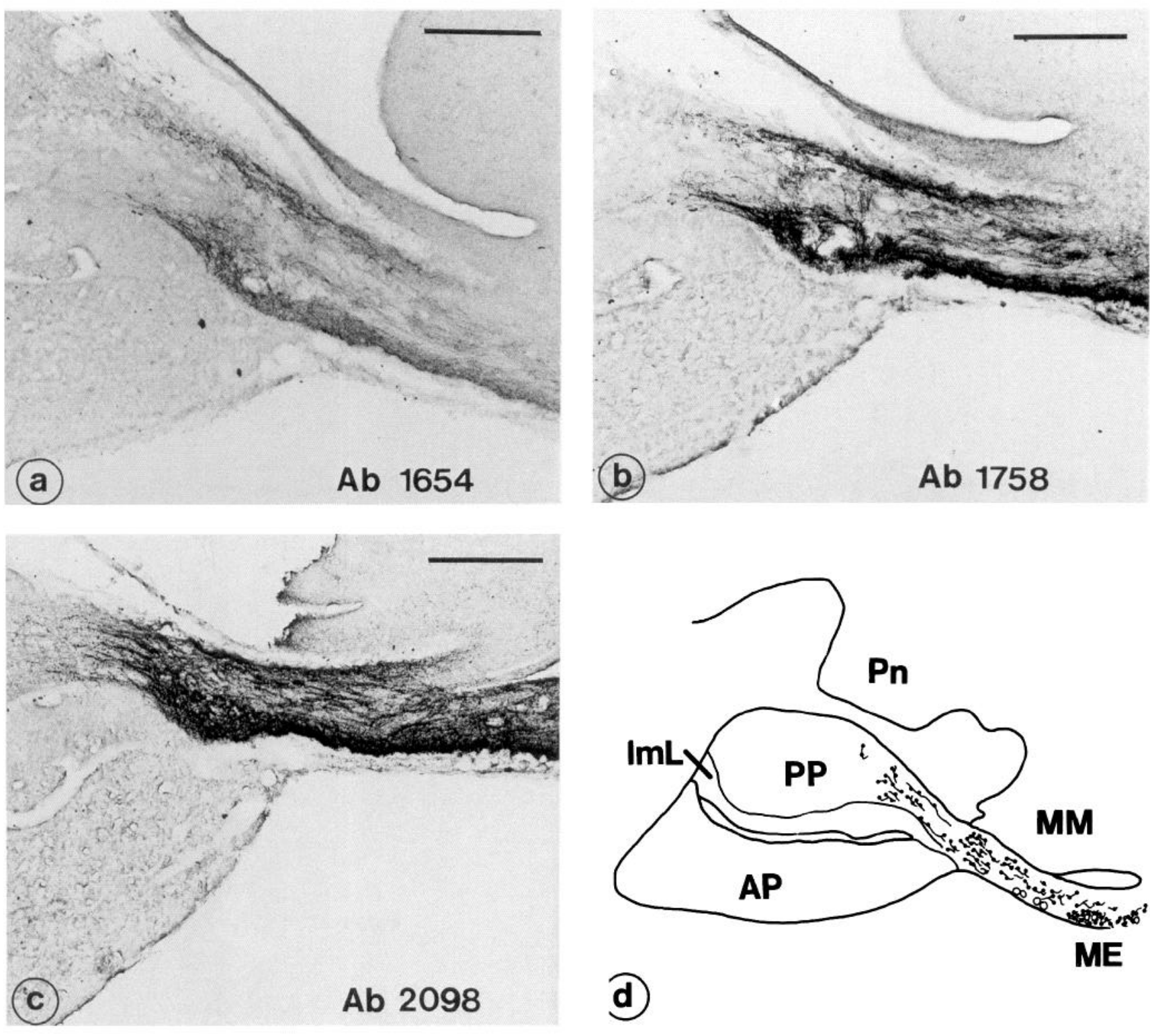

d)

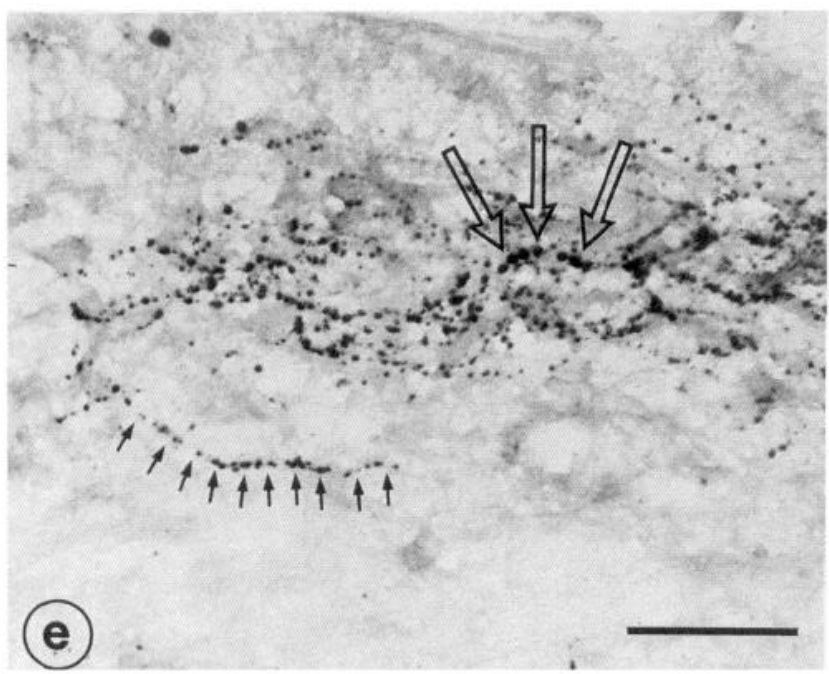

Figure 17. A series of medium-power photomicrographs from the gerbil pituitary stalk $(a-c)$. A dense plexus of SS-28-LI (a), SS-14-LI (b), and pro-SS-LI $(c)$ nerve fibers is seen in the external zone of the median eminence, whereas a lower density of immunoreactive nerve fibers is seen in the internal zone. The immunoreactive fibers are observed to course to the posterior pituitary lobe via the infundibular stalk. In $d$ a survey camera lucida drawing of the gerbil hypothalamo-pituitary complex is shown. Within the posterior pituitary (e), either thin immunoreactive fibers endowed with terminals en passant (small solid arrows) or large bulbous immunoreactive terminals (open arrows) are seen. For abbreviations, see Appendix. Scale bars: $a-c, 100 \mu \mathrm{m} ; e, 10 \mu \mathrm{m}$. 
Figure 18. Gel chromatographic profiles of extracts from hypothalamus (left column) and posterior pituitary lobe (right column). The amount of immunoreactivity is expressed as the total amount of applied immunoreactivity to the column. Elution positions of known fragments of the pro-SS molecule are depicted above each column.
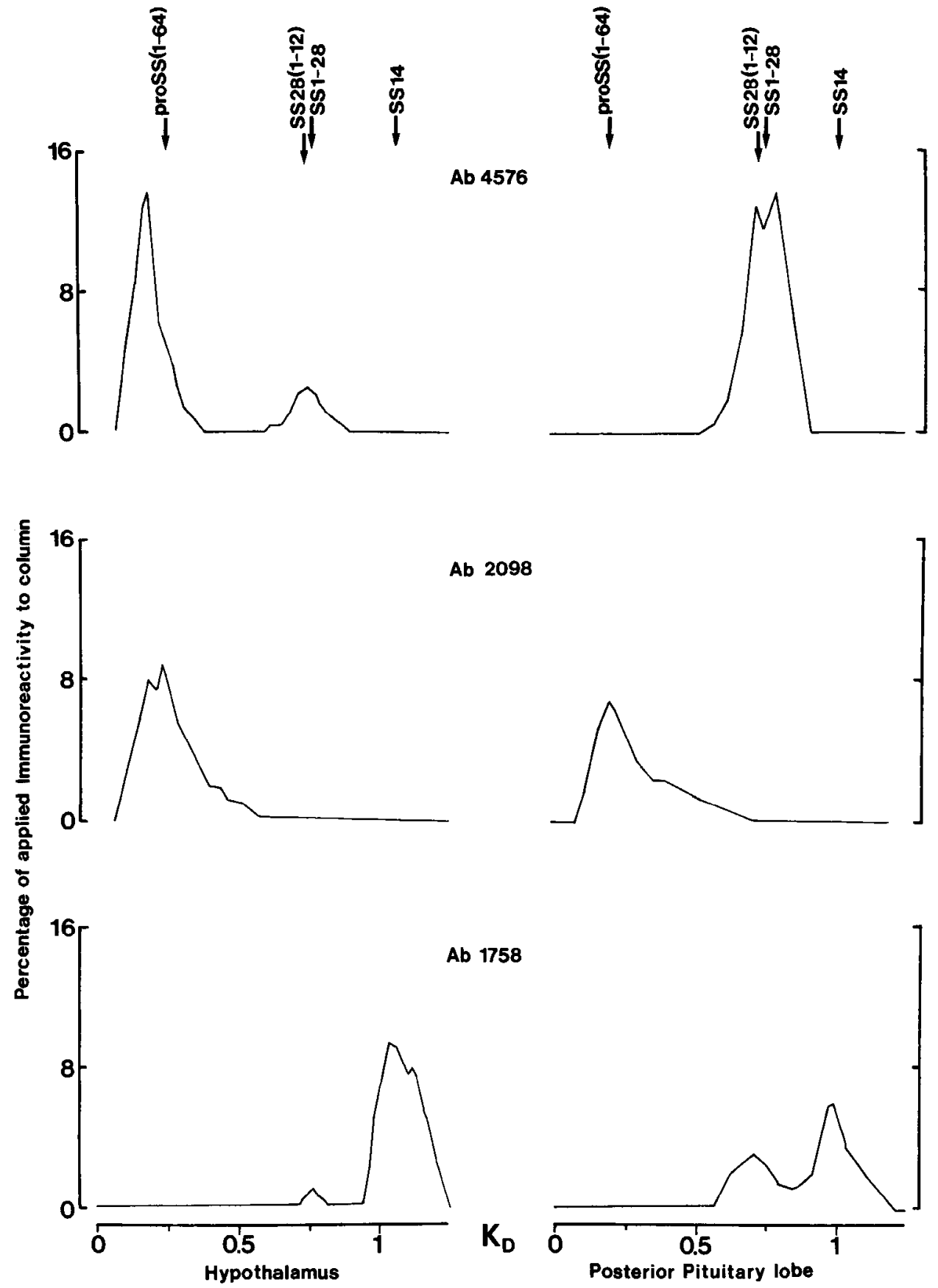

arcuate nucleus, the densities of neurons containing pro-SS mRNA, pro-SS-LI, and SS-14-LI appear to be similar in the examined cell groups. This seems to suggest a similar sensitivity of these two independent techniques and to the equal access of their reagents to the brain sections. The somatostatinergic neuroendocrine neurons in the periventricular area displayed the densest in situ hybridization signal and most intense immunohistochemical labeling of all examined cell groups. Since these cells are of comparable size to those observed in other hypothalamic areas, such as the area of the tuber cinereum, the higher grain density does not simply reflect a larger perikaryal size in this area. The regional differences in the amount of grains encountered per cell could be the result of larger synthetic activity of the periventricular cell group when compared to, for example, the area of the tuber cinereum as earlier suggested (Uhl and Sasek, 1986). The mismatch between a higher number of proSS mRNA-containing cells and the relative low number of proSS-LI and SS-14-LI cells observed for the arcuate nucleus could be caused by such diverse factors as small cytoplasmic storage capacity, fast axonal transport of newly synthetized pro-SS, and rapid cellular degradation of newly synthesized peptide. The mere presence of mRNA within a cell body does not always indicate that peptide synthesis takes place, as seen, for example, in the thalamocortical pathway where cholecystokinin mRNA was found (Burgunder and Young, 1988) but not cholecystokinin immunoreactivity (Innis et al., 1979). It may therefore be 
that only a fragment of the pro-SS message is actually translated within arcuate neurons.

In the preoptic area and hypothalamus, a differential regional distribution of SS-14-LI, pro-SS-LI, SS-28-LI, and SS-28(1-12)LI cell bodies and nerve fibers was observed. The observed differences were supported by the gel chromatographic analysis. The chromatographic data of hypothalamic extracts demonstrate the presence of two large and three smaller molecular species of the pro-SS molecule. About equimolar amounts of peptides coeluting with pro-SS(1-76), pro-SS(1-64), and SS-14 were present within the hypothalamus, whereas trace amounts of SS-28 and SS-28(1-12) were present. In general, this observation corresponds to the immunohistochemical observations. However, the presence of a pro-SS(1-76) fragment is surprisingly high compared to the immunohistochemical data inasmuch as only the presumably pituitary-projecting somata were properly stained with the 4576 antiserum. Abundant pro-SS(1-64)-like peptide has recently been reported to be present in rat hypothalamus (Rabbani and Patel, 1990), while the pro-SS(1-76) form was present in low amounts. This discrepancy could be either due to species difference or due to different extraction methods.

Earlier investigations have preferentially focused on the role of SS-14 and SS-28 in pituitary physiology (Rorstad et al., 1979; Tannenbaum et al., 1982; Reichlin, 1983), but the present data suggest that SS-28(1-12) could be a posterior pituitary neuroendocrine transmitter candidate. Within extracts from the posterior pituitary lobe, the large pro-SS(1-76) fragment was absent, indicating that it is further degraded during the axonal flow from hypothalamic cell bodies to the posterior pituitary terminals. This is not the case with pro-SS(1-64), which appears to be conserved during its course to the posterior pituitary lobe. We have recently reported a similar distribution of pro-SSderived molecular species in the rat posterior pituitary lobe (Mikkelsen et al., 1991). In extracts from the posterior pituitary lobe, the SS-28(1-12) fragment was by far the most predominant, while equimolar amounts of SS-28 and SS-1 4 were present. Several physiological experiments have shown that SS-14, SS28, and SS-28(1-12) all are released to the portal blood (Millar et al., 1983; Sheward et al., 1984; Pierotti et al., 1985). In the context of the posterior pituitary lobe being a distal extension of the median eminence, it is possible that a similar pattern of release takes place in the posterior pituitary lobe itself.

As shown in Table 2, the distributions of pro-SS-LI and SS14-LI cell bodies were equivalent. However, SS-28-LI and SS28(1-12)-LI cell bodies were restricted to hypothalamic areas known to send projections to blood-brain barrier-frec areas communicating through the vascular system with the anterior pituitary and the systemic circulatory system. The presence of a very low number of immunohistochemically stainable SS-28LI and SS-28(1-12)-LI perikarya compared to the number of SS-14 and pro-SS-LI perikarya was reflected by low amounts of extractable peptide. However, many areas contained SS-28LI and SS-28(1-12)-LI nerve fibers that were labeled nearly as intensely and were similarly distributed as that of SS-14-LI and pro-SS-LI nerve fibers. Keeping in mind that immunohistochemistry is an unreliable method for quantitative studies, it should be stressed that the concentrations of various pro-SS fragments are not necessarily identical. These observations suggest that the posttranslational processing of the pro-SS molecule within the intrahypothalamic cell bodies leads to the formation of three major SS-14, pro-SS(1-76), and pro-SS(1-64) pools, whereas the SS-28 and SS-28(1-12) fragments are further degraded. However, SS-28-LI and SS-28(1-12)-LI are present in nerve fibers, which could reflect either that these peptide fragments escape the posttranslational degradation within the cell bodies (not detected by immunohistochemistry) or that processing of the pro-SS molecule takes place within the nerve fibers, too. This is in agreement with earlier investigations, which have shown that within the hypothalamus, SS-14 is the most predominant peptide, whereas in the median eminence and the posterior pituitary SS-14 and SS-28 are present in equimolar amounts (Pierotti and Harmar, 1985), supporting the view that two populations of SS-containing hypothalamic neurons with different processing enzyme activity exist.

The hypothalamic nuclei and areas, in which pro-SS-LI and SS-14-LI cells were encountercd, harbor intracerebrally projecting neurons establishing synaptic contact with neurons in other brain areas. Within the brain, SS-28 exhibits three- and sixfold lower affinity than SS-14 to SS-14 receptors in the hypothalamus and cortex, respectively (Srikant and Patel, 1981; Leroux et al., 1985). On the contrary, the affinity of SS-28 to SS-14 receptors in the anterior pituitary lobe was 3.2-fold higher than that of SS-14 (Srikant and Patel, 1981). Based on the present results, it is tempting to speculate that SS-14 predominantly has neurotransmitter actions within the CNS, whereas SS-28 is more likely to exert a peripheral hormonal action mediated through a release to the portal and systemic blood circuit. SS14 as well as SS-28 exhibit an inhibitory effect of growth hormone from cultured rat pituitary cells, with SS-28 exerting a longer-lasting action than SS-14 (Tannenbaum et al., 1982). Hypothalamic areas exerting an apparently higher density of pro-SS-LI and SS-14-LI compared to SS-28-LI and SS-28(112)-LI were the suprachiasmatic nucleus, the medial portion of the ventromedial nucleus, and the arcuate nucleus. This could mean that the former peptides are more actively engaged in the regulation of these areas and thus influence functions such as circadian rhythmicity, food intake, and neuroendocrine control of the pituitary. However, the roles of SS-28(1-12), pro-SS(163 ) and/or pro-SS(1-64), and pro-SS(1-76), if any, are at present unknown.

The presence of somatostatinergic fibers in the posterior pituitary is controversial. In a recent study, Kawano and Daikoku (1988) did not show SRIF-LI in the posterior pituitary lobe of the rat. However, other studies have immunohistochemically confirmed the presence of pro-SS-related molecular species in nerve fibers within the posterior pituitary lobe of the rat (Hökfelt et al., 1975; Mikkelsen et al., 1991) and the dog (Hoffman and Haycs, 1979). Apart from the well known projection from the magnocellular PVN to the posterior pituitary lobe, additional projections arise from parvicellular PVN subnuclei and most of the hypothalamic periventricular nucleus (Swanson and Kuypers, 1980; Ju et al., 1986; Larsen et al., 1991). The immunohistochemically identified cell bodies in the present study were parvicellular and predominantly located in the periventricular hypothalamic nucleus, suggesting that these neurons contribute to the somatostatinergic hypothalamo-pituitary projection. The role of SS in the physiology of the posterior pituitary lobe is at present only speculative.

\section{Appendix}

The following abbreviations are used in the figures:

$3 \mathrm{~V}$, third ventricle

ac, anterior commissure 
AHA, anterior hypothalamic area

AMPO, anterior medial preoptic nucleus

AP, anterior pituitary lobe

Arc, arcuate nucleus

BST, bed nucleus of the stria terminalis

$\mathrm{cp}$, cerebral peduncle

DM, dorsomedial hypothalamic nucleus

f, fornix

fr, fasciculus retroflexus

GP, globus pallidus

HDB, nucleus of the horizontal limb of the diagonal band

ic, internal capsule

ImL, intermediate pituitary lobe

LA, lateroanterior hypothalamic nucleus

LH, lateral hypothalamic area

$\mathrm{LHb}$, lateral habenular nucleus

LPO, lateral preoptic area

ME, median eminence

$\mathrm{MHb}$, medial habenular nucleus

ml, medial lemniscus

MM, medial mammillary nucleus

MPN, medial preoptic nucleus

MPO, medial preoptic area

$\mathrm{mt}$ mammillothalamic tract

opt, optic tract

ox, optic chiasm

pePVN, periventricular parvicellular subnucleus

PF, parafascicular thalamic nucleus

$\mathrm{PH}, \quad$ posterior hypothalamic area

pmPVN, posterior magnocellular subnucleus

Pn, pontine nuclei

PP, posterior pituitary lobe

PV, paraventricular thalamic nucleus

PVN, paraventricular hypothalamic nucleus

$\mathrm{RCh}, \quad$ retrochiasmatic area

$\operatorname{Re}$ thalamic reuniens nucleus

SCN, suprachiasmatic nucleus

sm, stria medullaris

SO, supraoptic nucleus

sox, supraoptic decussation

SPF, subparafascicular thalamic nucleus

st, stria terminalis

TC, area of the tuber cinereum

VMH, ventromedial hypothalamic nucleus

$\mathrm{ZI}, \quad$ zona incerta

\section{References}

Baldissera FGA, Munoz-Perez MA, Holst JJ (1983) Somatostatin 1-28 circulates in human plasma. Regul Pept 6:63-69.

Beal MF, Domesick VB, Martin JR (1985) Effects of lesions in the amygdala and periventricular hypothalamus on striatal somatostatinlike immunoreactivity. Brain Res 330:309-316.

Bennett-Clarke C, Romagnano MA, Joseph SA (1980) Distribution of somatostatin in the rat brain: telencephalon and diencephalon. Brain Res 188:473-486.

Benoit R, Böhlen P, Ling N, Briskin A, Esch F, Brazeau P, Ying SY, Guillemin R (1982) Presence of somatostatin-28(1-12) in hypothalamus and pancreas. Proc Natl Acad Sci USA 79:917-921.

Benoit R, Böhlen P, Esch F, Ling N (1984) Neuropeptides derived from prosomatostatin that do not contain the somatostatin-14 sequence. Brain Res 311:29-39.

Bersani M, Thim L, Baldissera FGA, Holst JJ (1989) Prosomatostatin 1-64 is a major product of somatostatin gene expression in pancreas and gut. J Biol Chem 264:10633-10636.

Brazeau P, Vale W, Burgus R, Ling N, Butcher M, Rivier J, Guillemin R (1973) Hypothalamic polypeptide that inhibits the secretion of immunoreactive pituitary growth hormone. Science 179:77-79.

Brown MR, Mortrud M, Crum R, Sawchenko P (1988) Role of somatostatin in the regulation of vasopressin secretion. Brain Res 452: 212-218.

Burgunder JM, Young WS III (1988) The distribution of thalamic projection neurons containing cholecystokinin messenger RNA, using in situ hybridization histochemistry and retrograde labeling. Mol Brain Res 4:179-189.
Dierickx K, Vandesande F (1979) Immunocytochemical localization of somatostatin-containing neurons in the rat hypothalamus. Cell Tissue Res 201:349-359.

Enjalbert A, Bertrand P, Le Dafniet M, Epelbaum J, Hugues JN, Kordon C, Moyse E, Peillon F, Shu C (1986) Somatostatin and regulation of prolactin secretion. Psychoneuroendocrinology 11:155-165.

Fitzpatrick-McElligoll S, Card JP, Lewis ME, Baldino F (1988) Neuronal localization of pro-somatostatin mRNA in the rat brain with in situ hybridization histochemistry. J Comp Neurol 273:558-572.

Gomez S, Morel A, Nicolas P, Cohen P (1983) Regional distribution of the $M_{r}, 15,000$ somatostatin precursor, somatostatin-28 and somatostatin-14 in the rat brain suggests a differential intracellular processing of the high molecular weight species. Biochem Biophys Res Commun 112:297-305.

Goodman RH, Aron DC, Roos BA (1983) Rat pre-prosomatostatin. Structure and processing by microscopical membranes. J Biol Chem 258:5570-5573.

Hoffman G, Hayes TA (1979) Somatostatin neurons and their projections in dog diencephalon. J Comp Neurol 186:371-392.

Hökfelt T, Efendić S, Hellerström C, Johansson O, Luft R, Arimura A (1975) Cellular localization of somatostatin in endocrine-like cells and neurons of the rat with special reference to the A-cells of the pancreatic islets and to the hypothalamus. Acta Endocrinol (Copenh) [Suppl] 200:5-41.

Holst JJ, Åsted B (1974) Production and evaluation of glucagon antibodies for radioimmunoassay. Acta Endocrinol (Copenh) 77:715726.

Holst JJ, Baldissera FG, Bersani M, Skak-Nielsen T, Seier-Poulsen S, Nielsen OV (1988) Processing and secretion of prosomatostatin by the pig pancreas. Pancreas 3:653-661.

Ibata Y, Obata HL, Kubo S, Fukui K, Okamura H, Ishigami T, Imagawa $\mathrm{K}$, Sin S (1983) Somc ccllular characteristics of somatostatin ncurons and terminals in the periventricular nucleus of the rat hypothalamus and median eminence. Electron microscopic immunohistochemistry. Brain Res 258:291-295.

Innis RB, Correa FMA, Uhl GR, Schneider B, Snyder SH (1979) Cholecystokinin octapeptide-like immunoreactivity: histochemical localization in the rat brain. Proc Natl Acad Sci USA 76:521-525.

Ju G, Lin S, Tao J (1986) Projections from the hypothalamus and its adjacent areas to the posterior pituitary in the rat. Neuroscience 19: 803-828.

Kawano H, Daikoku S (1988) Somatostatin-containing neuron systems in the rat hypothalamus: retrograde tracing and immunohistochemical studies. J Comp Neurol 271:293-299.

Krisch B (1978) Hypothalamic and extrahypothalamic distribution of somatostatin-immunorcactive elements in the rat brain. Cell Tissue Res 195:499-513.

Larsen PJ, Møller M, Mikkelsen JD (1991) Efferent projections from the periventricular and medial parvocellular subnuclei of the hypothalamic paraventricular nucleus to circumventricular organs of the rat. A Phaseolus vulgaris leucoagglutinin (PHA-L) tracing study. J Comp Neurol 306:462-480.

Leroux P, Quirion R, Pelletier G (1985) Localization and characterization of brain somatostatin receptors as studied with somatostatin14 and somatostatin-28 receptor autoradiography. Brain Res 347:7484.

Lewis DA, Campbell MJ, Morrison JH (1986) An immunohistochemical characterization of somatostatin-28 and somatostatin $28(1-$ 12) in monkey prefrontal cortex. J Comp Neurol 248:1-18.

Lumpkin MD, Negro-Vilar A, McCann SM (1981) Paradoxical elevation of growth hormone by intraventricular somatostatin: possible ultrashort-loop feedback. Science 21 1:1072-1074.

Meyer DK, Conzelmann U, Schultheiss K (1989) Effects of somatostatin-14 on the in vitro release of $\left({ }^{3} \mathrm{H}\right) \mathrm{GABA}$ from slices of rat caudate putamen. Neuroscience 28:61-68.

Meyers CA, Murphy WA, Redding TW, Coy DH, Schally AV (1980) Synthesis and biological actions of prosomatostatin. Proc Natl Acad Sci USA 77:6171-6174.

Mikkelsen JD, Bersani M, Holst JJ, Larsen PJ (1991) Nerve fibers in the rat posterior pituitary lobe contain pro-somatostatin(1-64). Neuroendocrinology 54:469-476.

Millar RP, Sheward WJ, Wegener I, Fink G (1983) Somatostatin-28 is an active peptide secreted into hypophyseal portal vessel blood. Brain Res 260:334-337.

Newgard CB, Holst JJ (1981) Heterogeneity of somatostatin-like im- 
munoreactivity in extracts of porcine, canine and human pancreas. Acta Endocrinol (Copenh) 98:564-572.

Papadopoulos GC, Karamanlidis AN, Dinoppoulos A, Antonopoulos J (1986) Somatostatin-like immunoreactive neurons in the hedgehog (Erinaceus europaeus) and the sheep (Ovis aries) central nervous system. J Comp Neurol 244:174-192.

Patel YO, Reichlin S (1978) Somatostatin in hypothalamus, extrahypothalamic brain, and peripheral tissues of the rat. Endocrinology 102:523-530.

Pierotti AR, Harmar AJ (1985) Multiple forms of somatostatin-like immunoreactivity in the hypothalamus and amygdala of the rat: selective localization of somatostatin-28 in the median eminence. J Endocrinol 105:383-389.

Pierotti AR, Harmar AJ, Tannahill LA, Arbuthnott GW (1985) Different patterns of molecular forms of somatostatin are released by the rat median eminence and hypothalamus. Neurosci Lett 57:215-220.

Pradayrol L, Jörnvall H, Mutt V, Ribet A (1980) N-terminally extended somatostatin: the primary structure of somatostatin-28. FEBS Lett 109:55-58.

Rabbani SN, Patel YC (1990) Peptides derived by processing of rat pro-somatostatin ncar the amino-terminus: characterization, tissue distribution, and release. Endocrinology 126:2054-2061.

Reichlin S (1983) Somatostatin. N Engl J Med 309:1495-1501.

Reubi JS, Maurer R (1985) Autoradiographic mapping of somatostatin receptors in the rat central nervous system and pituitary. Neuroscience 15:1183-1193.

Rorstad OP, Epelbaum J, Brazeau P, Martin JB (1979) Chromatographic and biological properties of immunoreactive somatostatin in hypothalamic and extrahypothalamic brain regions of the rat. Endocrinology 105:1083-1092.
Schally AV, Huang W-Y, Chang RCC, Arimura A, Redding TW, Millar RP, Hunkapiller MW, Hood LE (1980) Isolation and structure of pro-somatostatin: a putative somatostatin precursor from pig hypothalamus. Proc Natl Acad Sci USA 77:4489-4493.

Shen L-P, Pichet RL, Rutter WJ (1982) Human somatostatin I: sequence of the cDNA. Proc Natl Acad Sci USA 79:4574-4579.

Sheward WJ, Benoit R, Fink G (1984) Somatostatin-28(1-12)-like immunoreactive substance is secreted into the hypophysial portal vessel blood in the rat. Neuroendocrinology 38:88-90.

Skak-Nielsen T, Holst JJ, Baldissera FGA, Poulsen SS (1987) Localization in the gastrointestinal tract of immunoreactive pro-somatostatin. Regul Pept 19:183-195.

Srikant CB, Patel YC (1981) Receptor binding of somatostatin-28 is tissue specific. Nature 294:259-260.

Swanson LW, Kuypers HGJM (1980) The paraventricular nucleus of the hypothalamus: cytoarchitectonic subdivisions and organization of projections to the pituitary, dorsal vagal complex, and spinal cord as demonstrated by retrograde fluorescence double-labeling methods. J Comp Neurol 194:555-570.

Tannenbaum GS, Ling N, Brazeau P (1982) Somatostatin-28 is longer acting and more selective than somatostatin-14 on pituitary and pancreatic hormone release. Endocrinology 111:101-107.

Uhl GR, Sasek CA (1986) Somatostatin mRNA: regional variation in situ hybridization densities in individual neurons. J Neurosci 6: 3258-3264.

Vécsei L, Widerlöw E (1990) Effects of somatostatin-28 and some of its fragments and analogs on open-field behavior, barrel rotation, and shuttle box learning in rats. Psychoneuroendocrinology 15:139-145. 